\title{
У FROM SYMPOSION TO GOȘṬHI: THE ADAPTATION OF A GREEK SOCIAL CUSTOM IN ANCIENT INDIA
}

\author{
Kenneth Zysk \\ University of Copenhagen
}

\begin{abstract}
The symposion, a male social gathering that began in ancient Greece, was a social institution by and for men, hence a type of men's society as we might understand it in modern parlance. Its manifestation on the Indian subcontinent has to date not been fully explored. In its original form, the symposion consisted of three main elements: alcohol, sex, and intellectual pursuits in the form of literature and philosophy, commonly understood by the popular phrase "wine, women, and song". These sympotic elements find their equivalents in a wide range of Sanskrit literature, which include medicine (Āyurveda), eroticism (Kāmaśāstra), polity (Arthaśāstra), epics, and rhetoric (Alaṃkāraśāstra), as expressed in the Carakasaṃhitā, the Kāmasūtra, the Arthaśāstra, the Mahābhārata and Rāmāyaṇa, and the Kāvyamīmāṃsā. The literary evidence indicates that the three sympotic elements came to full blossom in urban Indian men's social gatherings or gosththis dating to a few centuries before the Common Era. The paper combines this literary evidence with archaeological sources to show how a foreign social custom contributed to an indigenous institution of men's society in ancient India by a process of adaptation. It would appear that as the institution moved into different parts of the Indian subcontinent, it increasingly came under Brahmanic influence, which led to an important ideological change that stressed literary and intellectual pursuits over alcohol and sex. Under royal patronage, the goșthi finally became a means for the development of Sanskrit and Indian literature and drama.
\end{abstract}

\section{INTRODUCTION}

In recent years, J. Duncan Derrett has taken up as part of his studies of ancient India the topic of East-West interactions, especially as it pertains to Buddhism and Christianity. It is a risky subject at the best of times, but his conclusions merit closer attention. In his 2006 article "Versatility, Angle and Space: The Meaning of Buddhist and Non-Buddhist Parallels", he posits that "confabulation" occurred between the religious traditions of early Buddhism and Christianity, where the former borrowed "readily and self-consciously" from the latter (Derrett 2006: 240). In this paper, I should like to examine another form of confabulation, involving the cultural tradition of male social gatherings in ancient India and ancient Greece. I am not suggesting that the gathering of men to enjoy alcohol, sex, and intellectual discussion at special social events is unique to India

Volume 9(1) (2021), pp. 83-111

DOI $10.23993 /$ store. 102235

Licensed under Creative Commons 4.0 (CC BY-NC-SA 4.0) license. 
and Greece, for it occurs in one form or another in almost all antique and pre-modern cultures. ${ }^{1}$ However, the specific way in which it is described in the Sanskrit and Greek literature calls to mind Derrett's metaphor of the seed and water (Derrett 2006: 232). To paraphrase, if the seed was an Indian form of men's society, Greek ideas about the symposion seem to have watered and nourished it and helped it to flourish. I should, therefore, like to begin by looking at the special gathering of men called the sabhā in late Vedic times (1100-500 BCE) as a possible seed.

In his study of Vedic brotherhoods and dicing, Harry Falk discusses the sabha . Originally perhaps a place dug out of the ground, situated away from the house and set aside for dicing, it evolved in the late Vedic period into an institutionalised gathering of male companions where gambling was forbidden, but cattle were slaughtered and men enjoyed themselves under the direction of a leader by drinking alcohol and engaging in sex with prostitutes during the cool and dry time of Śiśira (mid-January to mid-March) (Falk 1986: 84-99). After that time, from the Buddhist period onwards, the rural sabha took on another meaning, referring to the occasional meeting of a large gathering or assembly of men, especially warriors, for the purpose of drinking, sex, and intellectual games, often under royal patronage. ${ }^{2}$ The same practices at the sabha occurred in a smaller, more refined gathering of men, known as goșthī, beginning in the early centuries of the Common Era. The blossoming of the goșthī, I maintain, probably resulted from the "watering" from the Greek symposion.

If we begin linguistically, we already find that there is precedent for the Greek word in Sanskrit, where symposion (sym-posion) and samāpānaka (sam-āpānaka) both occur in the context of the social gathering of men and mean "the act of drinking together". ${ }^{3}$ The term first appears in the work of the Greek author Alcaeus at the beginning of the seventh century BCE (Vetta 1996: 97), and in Sanskrit almost a millennium later in Vatsyāyana's Kāmasūtra, which scholars place between 250 and $400 \mathrm{CE}$ but which probably reflects an earlier time (Gomperts 2017: 139). The example of the translation of a Greek word into Sanskrit points to an important aspect of adaptation in ancient India. Rather than coming as a loanword, the foreign term was translated into the target language. In this way, it is given a Brahmanic or Indian nuance which the Greek original lacks. It indicates a second level of adaptation and integration beyond that of a simple borrowing of a word from another language. To illustrate further this process of adaptation, our study has generated a catalogue of other possible Greek-Sanskrit equivalents, which is appended at the end of the article.

Looking closely at the Sanskrit passages in relation to what is known about the Greek symposion from the Archaic through the Hellenistic periods (c.750-31 BCE), we can notice three dominant sympotic themes that reoccur in the literature of both languages: alcohol consumption, sex (homo- and heterosexuality), and mental agility. These three appear to varying degrees in different types of literature in ancient India beginning from the early centuries BCE, which would correspond to the middle of the Hellenistic period in ancient Greece. Examined closely, the Sanskrit passages reveal fundamental similarities with the symposion in ancient Greece. It is the configuration and understanding of this tripartite structure that receives special attention in

\footnotetext{
1 See, e.g., Dietler \& Hayden 2001; Dietler 2006; Jennings et al. 2005. Among the Indo-European peoples, see Das \& Meiser 2002.

2 In the epics, the $s a b h \bar{a}$, like the goșthī, was a place to tell stories (kathā) (Mbh 11.60.1 at 11.24.15), often about great warrior heroes like Bharata (Rām 2.63.5). Moreover, the description of Rāvaṇa's drinking hall (pānabhūmi) points to a large banquet room able to accommodate many people for a drinking binge (Rām 5.9).

3 Variations of the Sanskrit, including āpanna and even $p \bar{a} n a$, all from the root $p \bar{a}$ 'to drink', occur in the Kāmasūtra and the early medical literature.
} 
this study. The Greek symposion was the urban social context in which the three came together under one roof, as it were. The same three elements are distinctly visible in both military and urban environments of ancient India.

The Greek literature that reveals the many-sided aspects of the symposion is vast and extensive and supported by a substantial collection of material objects in the form of illustrated drinking vessels, all of which confirm its significance in the aristocratic life of the ancient world. In India, its elucidation also occurs in a variety of literary genres, including texts dealing with the medical treatment of the effects of alcohol, sexual pleasure, epic stories, and theories of poetry and drama.

The Sanskrit literature that illustrates the three sympotic elements will be examined, beginning with the medical compendium of Caraka, the Carakasamphitā, which reached its final compilation in early centuries of the Common Era, but which looks back to an earlier period. ${ }^{4}$ This is followed by the third- to fourth-century CE erotic manual, the Kāmasūtra, and enhanced with material from the Arthaśāstra, a treatise on Indian polity and administration, which, like the other two works, also attained its final version in the beginning of the Common Era. ${ }^{5}$ It provides the social and urban setting for the men's social gatherings and centres of courtly life. Both sex and alcohol afford thematic links in literature and entry points for the three sympotic themes. Along with these references to the men's social gatherings are those in the epics, whose dates range roughly from the same time period (a few centuries before the Common Era to a few centuries after), with parts of the Rāmāyana perhaps earlier. It is evident from these epic sources that the poets and the bards knew both the bacchanalian type of drinking binges involving soldiers, commonly associated with the sabha , and the more refined gatherings of elite men in society associated with the goșthī, even if there was overlap in both. The final source is Rājaśekhara's classic of literary criticism, the Kāvyamīmāṃsā, written in the ninth to tenth century CE. It offers a vivid picture of the symposion's intellectual element in its full development in India. In this way, the basic three sympotic elements are attested in the Indian literary tradition via three basic genres, each corresponding to one of the principal elements. Although there are overlaps, in general, alcohol consumption is dealt with in the medical literature, sex is found in the erotic literature supplemented with political literature, and intellectual activity is clearly observed in the literature of literary criticism, with epic literature illustrating elements of all three, but emphasising the first two (alcohol and sex).

Along with the drinking and sexual aspects of the symposion came a visible intellectual element aimed at demonstrating a man's mental agility. It took the form of the poetic compositions and stories of great heroes, and linguistic gymnastics involving extensive memory, both of which eventually became a princely undertaking involving large numbers of participants. As in ancient Greece, sympotic intellectual activities in India contributed to the development of poetry, drama, and other forms of literary composition.

The original three sympotic elements were not always found together in the Indian context. In the beginning, alcohol and sex predominated. At least by the early centuries of the Common

\footnotetext{
4 For the dating of this text and the early medical literature and their commentaries mentioned in this paper, the most reliable authority is Meulenbeld 1999-2002; on the dating of the commentator Jajjata more recently, one should consult Zysk \& Yamashita 2019.

5 Olivelle (2013: 25-31) dates the sources of the Arthaśāstra to between 50 and $125 \mathrm{CE}$, and what he calls the śāstric redaction that took place between 175-300 CE. These dates correspond to those of the Kāmasūtra, whose style also resembles that of the Arthaśāstra, and the final version of the Carakasaminitā.
} 
Era, all three elements came together in what was called the goșthī, which had both an urban and a rural form. The urban form comprised a type of male social gathering, where men met to dine, drink, enjoy women, and pursue literary and intellectual activities. In the rural form, it is called goșthika or goșthī, which appears to have been a type of organisation whose membership included men from the higher orders of society.

The Sanskrit word goșthi comes from goștha, which occurs in the earliest Sanskrit literature with the meaning 'cowshed'. In the epics, it is found mainly in similes with the predominant image of 'in the middle of the cowshed' (gosthamadhye), pertaining mainly to the bull. It conjures up images of both sex and procreation (Mbh 1. App. 115.46; 3.174.3; 4.31.19, 227.1, 378.9; $6.66 .5,107.34 ; 7.108 .29 ; 8.70 .2 ; 979.3 ; 12.232 .24 ; 13.198 .9$, App 4. 6.64; Rām 2.206.9; 5.4.1). The human side of the simile includes the derivative word gost thi and relates to men, particularly warriors. An illustration of this is the description of the young warrior King Citrasena after he had been shot with golden arrows: "the youthful (yuvan) king clad in variegated garlands and decorated with arrows looked radiant like a well-adorned youth in the midst of the gost hth" (Mbh 8.10.7). ${ }^{6}$ The goșthi , then, was a gathering of virile men, mainly soldiers, for the purpose of sexual enjoyment and procreation. In order to establish the conceptual parameters for the study, we shall begin by examining the central themes and meanings of the classical tripartite symposion in ancient Greece.

\section{THE GREEK SYMPOSION}

In the past decades, Greek traditions of eating and feasting have received a good deal of scholarly attention, especially by the British classicist Oswyn Murray, who single-handedly has set the standard for the study of the Greek symposion. The following overview of its basic elements owes much to his scholarship, along with that of others (Murray 1990; 2009; Cazzato 2018; Vetta 1996; Fisher 1988; Ford 2002; Vermant 1995; Vickers 1975; Blinkenberg \& Johansen 1924-1963; Melander 1999; Fischer-Hansen 2004; Valavanis \& Kourkoumelis 1996; Lissarrague 1990; Osborne 2014).

The symposion, which probably derived from the Homeric warrior feasts in about $800 \mathrm{BCE}$, took shape as an organised men's drinking party in the Archaic Period (750-480 BCE), and continued with little alteration into the Hellenistic period (323-31 BCE); however, changes in the classic symposion began to take place throughout this time. By 31 BCE, it was subsumed into the Roman convivium and became part of the royal banquet feast. As an essential custom of Greek culture, the symposion was adopted by the cultures with which Greeks came in contact, such as the Etruscans. It was a social institution by and for men, whose two patron deities, Dionysus and Aphrodite, symbolised the combining of wine with erotic pleasure, the main purpose of these men's gatherings.

Being first mentioned by the poet Alcaeus of Mytilene around $600 \mathrm{BCE}$, the symposion became the topic of numerous Greek authors, including Plato and Xenophon, each of whom in the fourth century BCE wrote a separate work describing a symposion at which the philosopher Socrates was present. Plato offers an idealised version where drinking was kept to a minimum,

\footnotetext{
6 At Rām 5.9.8, the wicked Rāvana appeared in the middle of his drinking binge like a bull in the midst of pristine cows (goșthe mahati mukhyānām gavām madhye yathā vrṣah). The way in which the drunken binge is presented in the Rāmāyana indicates it to be the practice of barbarians and reveals a fundamental dislike, if not disdain, for the custom associated with Rāvaṇa in the foreign land of Lānkā.
} 
and the focus of the symposion was a philosophical discussion on the nature of love, where agape replaced eros (Lamb 1925). Xenophon, on the other hand, presents a more realistic account where philosophy occupied a good deal of the aristocratic men's time, but where there was also place for satisfaction of the senses through entertainment before and erotic play after the philosophical discussion (Marchant \& Todd 1997). Bearing in mind these descriptions of the philosophical symposion in classical Athens, we proceed with a characterisation of the essential elements of the Greek symposion, which derives from a collection of sources. My aim is to establish the basic parameters of the Greek symposion and to elucidate the three principal sympotic elements.

\section{Characteristics of the Classical Greek symposion}

The symposion epitomised the leisurely aristocratic lifestyle in ancient Greece. It consisted of a body of men of equal status called companions (hetairos), who shared the same educational, social, and economic background. Aristocratic women were strictly forbidden, but slave women and special courtesans, serving as female companions (hetaira), were commonly present for the enjoyment of the men, making the symposion something purely for the amusement (euphrosyne) of upper-class men.

Men would come together in the evening on a regular basis. The events would be divided into two parts: dinner (deipnon/dorpon) and drinking together (symposion). After the meal was completed, the men began the business of drinking together in a special room (andrōn), which could be in or by the dining hall, but which was specially prepared for the consumption of alcohol. It might occasionally involve large numbers of men, when alcohol consumption would take place in a large hall (megaron). The number of attendees varied from a small gathering in a domestic abode to larger public feasts and drinking binges, which occurred less often. The room would be decorated in a festive manner and furnished with couches (kline) on which the men would recline, Middle Eastern-style, to enjoy wine, entertainment, and women. A leader (archos) or king (basileus) would be elected to guide the proceedings, which included the choosing of the number of mixing vessels (kratêr), the ratio of water and wine to be drunk, and the evening's entertainment. Before the actual drinking began, the leader would always conduct a ritual in which libations were made of undiluted and diluted wine to various gods, including Zeus, and to the spirits of the vineyard (agathos daimon). The ritual was accompanied by a vow uttered together (synomosia), uniting the drinkers and creating a bond between them (Vetta 1996: 97-98, 101; see also Murray 2009: 512, 515; Fisher 1988: 1173).

The drinking began with the distribution and consumption of the wine, weak at first, then gradually becoming stronger until a state of inebriation (kommos) was reached and the party moved into the streets. During the intervening period, the activities would focus on entertainment, song and poetry, and both homo- and heterosexuality, while wine was amply supplied.

The consumption of wine took centre stage, while the drink's potency was regulated by mixing wine with varying amounts of water. It was then cooled, strained, and finally served to the guests, who consumed it in special drinking vessels that went by different names, from the basic kylis to the elaborate kantharos, along with appetizers to stimulate thirst. Each man had his own drinking vessel, often illustrating the activities of an evening of wine and women. Games, such as the flicking of one's last drops of wine at a target (kottabos), would be played to ease the interaction between the various participants. As their tongues began to loosen, the men would begin to sing or recite poetry to the accompaniment of music played by flute girls 
and young male drummers, lending a theatrical atmosphere to the event. In the same way, the effects of the alcohol released the men's natural inhibitions, leading to sexual encounters. In the general sequence of sympotic elements, alcohol came first; this was followed by poetry and philosophy, and finally sex, as vividly represented on the drinking vessels of different participants (Lissarrague 1990: 102-122). ${ }^{7}$

\section{Poetry and intellectual activity at the symposion}

The poetry part of the symposion involved the participation of each member in the singing or recitation of a piece of verse (skolion), usually to musical accompaniment. It would either be literature they composed on the spot or borrowed from earlier poets they could remember. Each of the men sang in turn, leading to a chain of poetic creation or catena, anthologies of which were made and handed down. According to Vetta (1996: 103), these literary compositions exhibited skills in improvisation: "An opening utterance could stimulate others by a process of accumulation or corrections (metapoiesis), often reusing the same verbal material." ${ }^{\prime 8}$ Depending on the mood of the symposion, the creation could be elegiac poetry with flute accompaniment or lyric poetry with lyre accompaniment. As the men became more and more inebriated, their speech would become freer, often giving way to hubris expressed in iambic metre. Sometimes men would challenge each other in riddle games (griphos), in which the players had to find verses from Homer which started or ended with a particular letter or syllable. Such games sharpened the intellect and enhanced the memory. As we noticed in the descriptions of the symposion by Plato and Xenophon, the intellectual activity sometimes took the form of philosophical discussions.

Between the sixth and fifth centuries BCE, the literary involvement of the members of the symposion was taken over by professionals and the members became passive listeners. By the fourth century $\mathrm{BCE}$, a theatrical element was introduced when professional actors were hired to sing monodies, recite monologues, or enact whole scenes, as in the case of Xenophon's Symposiom. Dionysian technitai or artistic guilds eventually developed, giving place to various actors, poets, and artisans. At the same time, intellectual and philosophical discussions became common at the symposion, which included rhetoric, history, and sophistry (Vetta 1996: 102-104; Vermant 1995: 226, 246). Although a threefold form of the symposion was the norm, one or more sympotic elements could be emphasised, depending on the nature of the gathering.

\section{Sexuality at the symposion}

Along with literary entertainment came the sympotic element of erotic enjoyment, during which men engaged in both heterosexuality and homosexuality. The latter normally took place between an older lover (erastēs) and a beloved young boy (erōmenos), whom he introduced to the adult world of men by an act of homosexuality. The boy about to become a man was

\footnotetext{
7 The Danish National Museum and surrounding collections in Copenhagen have one of largest collections of illustrated drinking vessels and paraphernalia for the consumption of alcohol at the symposion. The sheer number and locations of the archaeological finds testify to the popularity of the custom among the aristocrats of ancient Greece. The collection is based on the "Vase-cabinet" from the collection of King Christian VIII, first exhibited in 1853 under the title "Antik-cabinette". These were supplemented by other collections in Copenhagen funded by the Carlsberg Fund. All collections have been catalogued and published in 10 fascicles under the auspices of the Union Académique Internationale and the Académie Royale des Sciences et des Lettres du Danemark (The Royal Danish Academy of Sciences and Letters): Blinkenberg \& Johansen 1924-1963; Melander 1999; Fischer-Hansen 2004.

8 See also Murray 2009: 510.
} 
admired for his youth and innocent beauty, the main objects of desire. Once initiated, the new man became an equal among men (Murray 2009: 519-520).

Heterosexuality was purely for fun. The female partners were special courtesans trained in the arts of pleasing men. They were often learned, and they played flutes (aulos), danced, or performed acrobatics. The special training they received included intellectual development that allowed them to carry on meaningful conversations with the men as part of their seductions. The high-paid hetaira resembled the Japanese geisha from a later period in East Asia. The sexual life of the symposion portrayed on the drinking vessels illustrated the importance of sexuality and drinking in the lives of the aristocratic men.

\section{The Macedonian symposion}

A form of the classical symposion which emphasised a large, banquet-style gathering, often of soldiers, was known in Macedonia, where Alexander first came in contact with it. For him, it was a regular event with lavish entertainment by professionals, which included "jugglers, actors, competitive quotations from Homer, set debates, and, of course, excessive drinking" (Fisher 1988: 1189). During the Hellenistic period (323-32 вСE), it was the standard entertainment at court, where the king provided the andrōn in the form of a great hall and the sympotic conversation included literary genres appropriate for large numbers of military men and aristocrats. The presence of soldiers tended to limit the scope of the conversation and favoured the symposion's Dionysian aspects of drinking and sex.

The Greek symposion was a central feature of Greek society and culture, which remained relatively constant through time and existed wherever Greek influence was found. It is not surprising, therefore, to find a form of it represented in ancient India, where it shared elements found in the descriptions of the goșthi

\section{SYMPOTIC ELEMENTS IN SANSKRIT LITERATURE}

Although an exact reproduction of the Greek symposion could hardly have been expected in India, the three basic sympotic elements are manifested in different types of Sanskrit literature. We begin with an elaborate description of a drinking event (āpāna, pāna), reminiscent of the symposion, from early medical literature. The version found in the Carakasamhitā is arguably the earliest example in Indian literature in which may be found a description that closely corresponds to the typical Greek symposion outlined above.

\section{The drinking binge in the Carakasamhitā}

Located in the chapter on the treatment for the bad effects of intoxication (madatyayacikitsita), the account of a typical drinking binge takes on the character of a clinical description, such that essential sympotic parts are clearly discernible.

A man who has carried out his bodily preparations; who is clean, perfumed with the best scents and dressed in unsoiled clothing permeated with the seasonal scents; who is adorned with different kinds of variegated garlands and embellished with jewels and ornaments - first paying homage to the gods and twice-born upper classes and touching something auspicious - is seated on a lounge chair (śayanāsana) arranged with scattered cushions or placed comfortably crosswise (on it) at a preeminent, auspicious, and seasonal place (deśa) infused with flowers, approved by ones with an aesthetic taste, and distinguished by the fragrance of incense. 
He should always drink from clean vessels (bhäjana) made of bejewelled gold and silver or others that are stylish. Being brought together with desirable girls (pramada), who are intoxicated with beauty and youth and especially learned (sikșita); who are embellished with seasonal clothing, ornaments, and wreaths; who are pure and passionate; and who move about serving drinks, he should drink the very best alcohol, along with various kinds of appetizers, seasonal fruits and ripe green vegetables, salts, and fragrant and pungent foods, as well as various kinds of roasted meats from terrestrial, aquatic, and avian animals and variously composed foods by royal chefs. [He should begin drinking only] after he has first paid homage to the gods, uttered the blessings, and offered alcohol mixed with water (sajalam madyam) on the surface of the earth for the desirous spirits. ${ }^{9}$

First, a man who joined such a drinking party would prepare himself for the evening by wearing clean and scented clothing and adorning himself with garlands, jewels, and ornaments, which aptly fits the above-mentioned description of the well-adorned youth in the middle of the goșthi from the Rāmāyana. The venue was simply called a preeminent and auspicious place or district (deśa) appropriate to the season, which was aesthetically decorated and characterised by its fragrances. ${ }^{10}$ Here the men were comfortably seated crosswise on a lounge chair (śayanāsana) scattered with cushions.

The preparation of the alcoholic drink is not mentioned in this passage, but a process of mixing alcohol with water is implied at the end, where it says that before the drinking begins homage was paid to gods with blessings (ásis) and a libation of alcohol with water (sajalam madyam) offered for the sake of those desiring spirits (arthin), who are listed by the different commentators as different divine and semi-divine entities. ${ }^{11}$

The alcohol was always drunk from stylish, clean, and bejewelled vessels (bhäjana) made of gold and silver, which were kept filled by attractive, passionate, and nubile women (pramadā) who were learned and appropriately adorned. Accompanying the drinks were various seasonal appetizers and meats from different animals, all of which were prepared in the royal kitchen. The passage describes an early form of banquet-type goșthi $\bar{w}$ with clearly discernible sympotic elements. ${ }^{12}$

Certain sympotic elements of the drinking binge mentioned in this passage fit only the Indian context and give it Indian nuances. They included local brews of Indian alcohol and Indian forms of rituals involving libations, as well as clothing, adornments, and entertainment. The inclusion of food from the royal kitchen at the drinking party indicates first that it was more of a banquet than a purely drinking event and, secondly, that it was an occasion that took place

\footnotetext{
9 CaCi 24.11-20. The translation derives from an examination of the earliest commentaries of Jajjata (seventheighth century $\mathrm{CE}$ ) and Cakrapanidatta (eleventh century). The Sanskrit text of this and the following translation are not supplied, since readers can easily consult the bibliography for the editions that were used. Variants are found in the later summaries of the Aștāngasamgraha and Aștāingahṛdayasaṃhitā, both probably from the seventh-eighth century CE. At AsCi 7.77ab (= AhCi 63ab), the term goșthi first appears. It states that without alcohol (surā), goșțhīs, great festivals, and royal gardens would all lack sparkle (goșthìmahotsavodyānam na yasyāh śobhate vināa). Corresponding passages are wanting in the Suśrutasamhitā and Bhelasamnitā, both of which are later than the Carakasaṃhitā, but probably before the later Vāgbhața compilations (As and Ah).

10 The seventh-century variants embellish the place set aside for drinking, which reflects both the Greek symposion and the Indian gosthī. It was specifically called the "refuge for drinking" (apannabhümi) and was located near the dining hall, where there were gathered friends, servants, mistresses, groups of storytellers, travelling bards, and coquettish women who sang and danced to the accompaniment of instruments (AsCi 9.89-91; AhCi 7.75-77). 11 Jajjaṭa lists them as Baladeva, yakṣas, rākṣasas, piśācas, etc.; Cakrapāṇidatta as Baladeva, Caṇdī, yakṣas, etc.; and Arunadatta has devas, dānavas, Kūṣmāṇ̣ā (Durgā), etc. The later compilations also specified that the alcoholic beverage was cooled by buds and flowers and by breezes (AsCi 9.95; AhCi 7.83), which reflects a sympotic influence in the preparation of alcoholic drinks by means of the mixing vessel (kratêr).

12 A not too dissimilar description of a drinking binge takes up a full chapter in the Rāmāyaṇa (5.9), when Hanumān in search of Sìtā enters Rāvana’s drinking hall (pānabhūmì) after a drunken binge. The scene resonates with the large symposions of ancient Greece and included women educated in the arts of pleasing and arousing men.
} 
under the auspices of royal patronage. Both of these characteristics reflect Indian adaptations inspired by the Greek symposion, being perhaps modelled on the Macedonian version.

Further along in the same chapter, Caraka provides a clear description of the male companions (sahāya) at the drinking binge, where there occurs an allusion to the distinctive sympotic element of homosexuality.

\begin{abstract}
A man is happy when he drinks with the following companions (sahāya) in a drinking party (pāna): those who are well-behaved and well-spoken; who have a pretty face (sumukha) and are acceptable to good men; who are acquainted with the arts $($ kala $)$, cheerful, and obsessed with objects of the senses; who are submissive to one another (parasparavidheya) and with whom unity is obtained through their friendship; who enhance the drinking (āpana) with their arousal, affection, and sweetness (praharșapritimädhurya); and whose merriment is even more jubilant when they see each other. Those good companions are equal by virtue of their (shared) proper behaviour. They drink (together) when they are connected by their handsomeness, scent, essential juices, touch, and words that gratify the mind (rüpagandharasasparśair śabdaiś cāpi manoramaih). With the five sense objects sought, obtained, and pleasing to the mind, he should drink alcohol with an aroused mind at a specific place and time. ${ }^{13}$
\end{abstract}

Another description of male companions (sakhi/vayasya) from the contemporaneous Rāmāyaṇa also reveals veiled references to homosexuality. In order to cheer up the depressed hero Bharata, his male companions surrounded him and spoke affectionate words (priyavädi), told jokes at the goșthi (goșthīhāsya) and stories (kathā) at the sabhā, played musical instruments (vādayanti), created tranquillity with their dance (śāntim lāsayanti), and performed (nātaka) (Rām 2.63.3-6).

These passages describe the young male companions who attend drinking affairs, such as the large sabha and the intimate goșthi. The language used to describe them indicates that they were probably not fellow fighters, but young boys about to enter adolescence, who still had the qualities of affection and innocence. The allusions to homosexuality in these texts reflect those associated with the Greek symposion; thus, male-to-male sexual encounters were probably an integral part of the activities of the male gatherings where boys were initiated into the men's special society by being transformed into men. The lack of explicitness in the Sanskrit texts probably results from an aversion to homosexuality among both the Buddhist and Brahmanic intelligentsia of India. Moreover, the absence of the verses in the subsequent medical compilations of the Aștānngasaṃgraha and Aștāngahṛdayasaṃhitā indicates deliberate removal, supporting the view of an Indian antipathy towards homosexuality, since it ran counter to the dominant Brahmanic ideology of sex for the procreation of male offspring, a theme repeated in the chapter on potency therapy in the Carakasaṃitā; according to the commentary, celibacy (brahmacarya) is permitted on religious grounds (Zysk \& Yamashita 2019).

The literature of early Indian medicine provides a picture of a drinking binge, focusing on alcohol and sex, and where clear sympotic elements are identifiable. However, the passages

$13 \mathrm{CaCi}$ 24.80-84. The seventh-eighth-century commentator Jajjața explains that those companions who drink, gratified with respect to handsomeness and so forth, are equals by means of their virtues. It is because they mutually share these qualities. He adds that the last verse is a precept verse, so that in the end, one should drink alcohol with an aroused mind in a particular place and at a particular time. The commentator indicates that it be regarded as a type of ritual one might have encountered among early followers of tantrism. In the eleventh century, Cakrapānidatta explains that they increase the propriety (prasāda) of drinking, not its addiction (prasakti), because that is forbidden ( $\operatorname{tasya} \bar{a}$ ninditatvāt). 
also reveal a process of adaptation, perhaps by imitation, which is distinctively Indian. These include especially the affectionate behaviour of the male companions.

In the Sanskrit treatise of the Kāmasūtra, all three primary sympotic elements are brought together in the context of the gost thi . The text provides a colourful account of the life of cultivated, upper class, urban gentlemen; and for the first time, it provides a clear aristocratic underpinning to the activities that found place among generally smaller and more intimate gathering of men in venues that included brothels and private homes, as well as large public spaces within the confines of the court.

\section{Sex and Drinking in the Kämasütra}

Written in terse prose, the Kāmasūtra is a manual of proper social behaviour for aristocratic gentlemen (nägaraka) in matters pertaining to their pleasurable pastimes in the cities and the royal courts from the end of the BCE period to about the fourth century CE. Like the men of the symposion, the male citizens came from the elite strata of society.

Because of the adumbrated style of the Kāmasūtra, Yaśodhara's thirteenth-century commentary, the Jayamangalā, is required to complete the text and give it meaning. It must be used with caution, however, because in addition to filling in the missing pieces, it adds information that may in fact reflect ideas and practices from its author's own time. An understanding of the urban environment of the male gatherings comes from another Sanskrit source from about the same time.

A picture of a typical urban setting in which such a city-dwelling man might have lived emerges from the Arthaśāstra, whose fourth chapter in the second book describes the fort with its living quarters with restricted access (durganivesa). The fort was laid out so that the royal residence (antahpura) was in the centre, around which in the various directions were situated the residences of the other upper-class inhabitants and royal suppliers (AŚ 2.4). The male citizen would have had access to all these separate living areas within the fort. A man residing in the urban environment also enjoyed a particular kind of life style that indicated he was from the aristocratic segment of society, and his typical day consisted of little work but many pleasurable pastimes.

In setting out the ideal routine of an urban gentleman, the Kāmasūtra prescribes that in the afternoon, he, being appropriately dressed, should amuse himself with the pastimes at the goșthi $\bar{i}$; and in the evening, he should attend musical performances. At the end of the day, he and his friends should sit with pre-arranged courtesans (abhisārika $)$ on couches (śayya $)$ in his own specially prepared and scented room (vāsagrha) within his residence. At this séance, the men should attend to the women in order to win their affections for a night of sexual pleasure (1.4.22-25).

The programme recommended an afternoon in the company of men at the goșthī, followed by entertainment, and then capping off the day with an evening in the company of male friends in the enjoyment of sensual pleasures with women. His visit to men's social gathering, therefore, often took place before the evening of music and sexual pastimes. Among the different activities in which he participated, the male citizen enjoyed the company of men at the gosth $\bar{\imath}$ and engaged in binge drinking ( samāpānaka) with male companions. Once a fortnight or once a month, he took part in a ritual to the goddess of eloquence and learning, Sarasvatī (1.4.26-27). In addition to the connection between the common drinking parties and the goșthi, the mention of regular rituals to Sarasvatī illustrates a distinctively Indian sympotic element, where the goddess of eloquent speech is the Indian equivalent of the Greek Sophia. The following detailed description of the men's social gathering reveals further sympotic underpinnings. 


\section{The goṣtḥī}

The Kāmasūtra defines the goșthī as a specific arrangement of seats (äsanabandha) found in three different locations: a brothel (veśyābhavana), a large assembly hall $\left(\right.$ sabhāa) ${ }^{14}$ or the dwelling (udavasita) of another male citizen. The men who gathered there were of the same age and came from a similar social background. They enjoyed a common basis of knowledge, intellect, behaviour, and wealth; and they sat together with the courtesans and engaged in fitting conversations with them on sophisticated themes (1.4.34).

The activities at the men's club included literary and intellectual pursuits in the form of the joining of verses ( $k \bar{a}$ vyasamasya $)$ in poetic composition, and discussions of the sixty-four different arts (kalāsamasyā).$^{15}$ According to the Mahābhārata, goșthīs were also venues, along with palatial mansions (prāsāda) and domestic abodes (āvastha), where bright (śobhana) Sanskrit scholars (pandita) congregated to compose various stories (kathā vicitrāh kurvānāạ) (Mbh 4.42.27). Goșthīs were, then, not only events where men gathered to drink and have sex; they were also occasions for intellectual pursuits, where Sanskrit scholars would sometimes attend. The inclusion of Brahmans points to an important Indian adaptation of the sympotic paradigm. In the matter of heterosexual enjoyment, the protocol required that lovely local girls (lokakantā) should be obtained by a servant and treated with respect and honour (1.4.35-36).

In these brief lines of Sanskrit prose, we obtain a unique glimpse of the Indian gosthi $\bar{l}$ and the activities that took place there. Drinking occurred in a special room, which could be found in a variety of locations. The male clientele who participated in the goșthi behaved in a respectful manner and engaged in intellectual pastimes. The women were specially chosen to gratify the men's sexual desires. All three of the basic sympotic elements (alcohol, sex, and poetry) are present in the Kāmasūtra's discussion of the goșthī. Noteworthy are both the venues for the gatherings, one of which was the sabha or large assembly hall, and the inclusion of Sanskrit scholars at the event. Conforming to the Brahmanic principles offered at the beginning of the Kāmasūtra, the emphasis was on heterosexuality. These basic characteristics illustrate Indian adaptations of the Greek symposion.

The commentator Yaśodhara provides a slightly more nuanced version of the men's gathering, which to some extent probably represents the goșthi $\bar{\imath}$ as he understood it during his time. He defines it as an assembly of men who drink and eat together (sambhūya pānabhojana) for the purpose of fun, and which the wives of respectable men might also attend. ${ }^{16} \mathrm{He}$ clarifies that the men sat together with courtesans at the gatherings in order to engage in conversation with them on topics pertaining to knowledge of the arts and that the seating arrangement of the men was prearranged (1.4.34). The commentator's information fills in the missing parts of the original text. However, the blending of eating and drinking and the participation of respectable women are missing from the classical Greek sympotic paradigm and are not mentioned in the root text of the Kāmasūtra. They likely represent a version of the goșthi that was known during

14 The sabhā mentioned here probably refers to the later large assembly hall, where the men could meet. Naturally this would be a big event where numerous couches were arranged. It corresponds to the Greek megaron. Goșthī and sabhā occur together in the Rāmāyaṇa as two places where stories and jokes are told (2.63.5; insert to 11.24.15). One could presume that the latter was a large and the former a small gathering of men.

15 A list and discussion of the sixty-four arts comprise the topic of a full chapter in the Kāmasūtra (1.3). For a further analysis of the different lists of art $(k a l \bar{a})$ and knowledges (vidya $)$ from different Indian sources, see Venkatasubbiah 1911; Venkatasubbiah \& Müller 1914.

16 See also KS 4.1.15, 6.1.13. 
the commentator's time. As in the medical account, there is mention of the role of the women and the seating of the pairs.

The commentator also embellishes the description of the sympotic element of mental agility

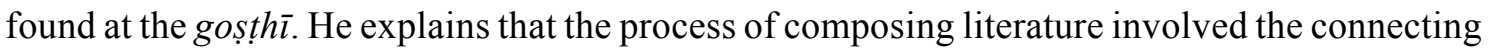
of verses from such well-known works as the Mahābhārata and academic discussions of topics from the list of arts $(k a l \bar{a})$, beginning with performance (natya $)$ (1.4.35). Both took place at the goșthi and had different purposes. The connecting and improvising of verses relied on the memorisation of major works of literature and challenged the skill of composers to create poetry; the discussion of the arts required analytical acumen and a wider appreciation of knowledge and aesthetics. Both, as we have seen, were aspects of the classical Greek symposion. Yaśodhara's description of the intellectual element of the goșthi imitates a form of the sympotic skolia and verse improvisation, in which verses from the epics are linked together in a chain, but it also reflects a philosophical side of the discussion, as exemplified in the versions of the symposion offered by Plato and Xenophon. The structure was the same, but the topics chosen for discussion were typically Indian.

The Kāmasūtra also provides details about the sympotic element of sex, which is the main topic of the treatise. At the end of the mental gymnastics, the sexual part of the programme was initiated by the fetching of the local girls (1.4.36). Elsewhere in the treatise, it explains that it was often the case that there was one woman for many men (2.6.45). All that a man needed do was present girl with a flower on her way to the gosth $\bar{\imath}(5.2 .21)$ in order to secure her for his evening's sexual pleasure. The women were chosen for their affections and brought to the goșthī by pimps (vita). From then on, they became part of the goșthì s harem $(6.1 .13,6.47)$.

Like the Greek symposion, the Indian goșthi included all three sympotic elements for the sole amusement of upper-class, aristocratic men. Unlike the earlier medical version of the drinking party in which homosexuality played a role, the passages from the Kāmasūtra emphasise heterosexuality as an essential sympotic element of the goșthit. The absence of any specific mention of homosexual encounters does not imply that they did not exist; it simply points to an adjustment of the institution to accommodate a strictly Brahmanic social context as an essential aspect of adaptation.

\section{Common drinking parties}

In addition to sex and mental gymnastics, the Kāmasūtra includes a description of drinking parties (apānaka). It states that common drinking took place with fellow males on a rotating basis at the residence (bhavana) of a male citizen (1.4.37). Yaśodhara explains that these drinking sessions took place either once a fortnight or once a month and were specifically called drinking goșthīs (pānagoșthī).

Prostitutes (veśyā) were also present at these events, as they first supplied men with alcoholic drinks and then partook of the beverage themselves. The alcoholic drinks consisted of the basic kinds of distilled and fermented Indian drinks, called mādhvīka, maireya, sūra, and asava; as in the Carakasamphitā, they were served with different kinds condiments, consisting of salty fruits, yellow vegetables, and spices with bitter, hot, and sour tastes (1.4.38), no doubt with the aim of increasing thirst. Yaśodhara further expands on the different kinds of alcoholic drinks and explains that the courtesans partook of the drinking along with the men. They both drank from a common goblet (saraka). He emphasises that under all circumstances the men must show sexual restraint and always observe local customs. Here again the commentator 
provides the missing pieces that complete the image of the Indian form of the drinking party; but his list of alcohols and condiments might also pertain to a later time.

The contemporaneous Arthaśāstra supplies further information about alcohol in the forts and cities of the time, which included a special alcohol merchant (surāpanya) whose residence was located in the southern quarter of the fort (AŚ 2.4.11). ${ }^{17} \mathrm{He}$ was responsible for all things related to the sale, distribution, and consumption of alcoholic beverages (AŚ 2.25.1-11). Of the four types of drinks mentioned in the Kāmasūtra, the Arthaśāstra provides recipes for maireya and $\overline{a s a v a}$, and it includes medaka, prasannā, arișta, and madhu. The arișta was an alcoholic preparation found in the medical literature. The drink madhu was made from the juice of grapes (mrrdvīkārasa) and has the names Kāpiśāyana and Hārahūra based on the regions, probably in the north-western regions of the subcontinent, whence they came (AŚ 2.25.16-25; See Olivelle 2013: 565-566). Since Kāmasūtra's $m a \bar{a} h h v \bar{k} k a$ derives ultimately from madhu, it likely referred to a type of wine made from grapes and imported from the north-west.

The Kāmasūtra's description of the common drinking event resembles the depiction of the symposion portrayed in the Greek sources and found on the special Greek drinking vessels (Blinkenberg \& Johansen 1924-1963; Melander 1999; Fischer-Hansen 2004; Valavanis \& Kourkoumelis 1996), where both men and women participated and the women were special courtesans. Rather than wine, the alcoholic beverages consumed consisted almost exclusively of indigenous fermented and distilled forms of alcohol, which were served with various kinds of foods and spices. Wine was likely imported from the north-west for those who could afford it and was probably reserved for special occasions. The alcoholic drinks are clear sympotic adaptations replacing wine.

None of the Indian versions thus far examined mentions the equivalent of sympotic games (kottabos) or the state of inebriation (kōmos) commonly found in the Greek sources; however, the latter could be assumed in the medical version, which deals with the harmful effects of alcohol consumption.

The section of the Kāmasūtra closes with a decree that the male citizen had the obligation to encourage like-minded men who lived in the outlying villages to start up goṣthis that would engender prestige and respect (1.4.59). Three summary verses meant to be memorised complete the chapter. Forming a kind of oath that extolls the virtues of the male citizen and the men's social gathering, they specify that an esteemed male citizen should use a blend of Sanskrit and the vernacular language when discussing the subjects at the male gatherings and that the male citizen should only join a gosth $\bar{\imath}$ with the following characteristics: it is approved by the people, it does only good, it is selective about who is admitted, and it is only for the purpose of fun $(k r i \bar{d} \bar{a})$. I quote these three verses in full, since they were meant to capture the essence of the chapter (1.4.50-52).

Using neither Sanskrit nor vernacular language in excess when discussing the subjects in the gosth $\bar{\imath} \mathrm{s}$, [the male citizen] becomes highly esteemed in the world.

The wise man should not participate in a goșthi that is disregarded by the people, that increases its number at will, and that has the nature of corrupting others.

The intelligent man, who associates with a gosthi that conforms to the thoughts (citta) of the people and that has amusement (krī $\bar{a})$ as its only purpose, obtains success in the world.

17 See also Olivelle 2013 for the most up-to-date scholarship on the Arthaśāstra. 
Both the decree and the oath reflect Indian adaptations. Rural men's gatherings or gosthikas are also known from inscriptional sources. Information about them is scarce, but the information that is available points to a man's social institution that has spread from the urban to the rural setting as prescribed in the Kāmasūtra.

Inscriptional evidence gives an idea of some of the non-urban male members of the gosthit, called goșthikas, or "little goșthiss," in the rural areas of both north and south India from about the fifth to the twelfth century $\mathrm{CE}$. These men are described as wealthy members of the local council or assembly, who were often charged with administrative responsibilities involving temples or sections of land in return for compensation in the currency called drachma. The sources indicate that these assemblies included members who were educated and knew something about finance and administration (Bühler 1892: 190; Kielhorn 1896-1897: 309; Mirashi 1937-1938: 331-332; 1955: 21; Subrahmanya Aiyer 1937-1938: 27-42; Gai 1959-1960: 47; Hultzsch 1882: 339). They were among the social elite in rural India. The evidence does not permit us to know if these rural goșthis included any or all of the basic sympotic elements. They were simply gatherings of influential and wealth men living in the countryside.

Various Sanskrit terms for men and women associated with the goșthī in the Kāmasūtra provide a more nuanced view of the social gathering. In addition to the male companion (sahaya) of the Carakasamhitā, and the sakhi/sakha and vayasya of the Rāmāyana, the Kāmasūtra has both the nāgaraka 'urban male citizen' and their nayaka 'leader'. The nāgaraka of the Kāmasūtra no doubt bears a close resemblance to the nāgarika or nagara of the Arthaśāstra, which Olivelle $(2013: 106,175)$ translates as "city manager", who was an important member of upper-class urban society. His principal duties centred on the maintenance of the city (nagara) (AŚ 2.36.1, 42-43; see also Olivelle 2013: 177, 581-582). It would appear that the male citizen described in the Kāmasūtra represented a general class of urban men, exemplified by the city manager of the Arthaśāstra. These men were not from the nobility but nonetheless shared a high standing in society.

The nāyaka is known as a hero or paramour in Sanskrit poetry and drama. Coming from the Sanskrit root $n \bar{l}$ 'to lead', the word has the principal meaning of 'leader', which in the context of the goșthi is the equivalent of the Greek archos or basileus, the leader of the day's activities or master of ceremonies. His qualities included proper behaviour at male social gatherings, drinking parties, and amusements. His female equivalent was the nāyika , the head or madame of the goșthìs harem, whose qualities included affection for both the goșthi and for the arts (KS 6.1.12). Another Sanskrit word that occurs in connection with the gosthth is vita, which is best understood by the English word 'pimp'. The person's sole purpose was to obtain women to be the ladies of the goșthi .

While the Carakasaṃhitā and Rāmāyana simply use the term "beautiful young girls" (CaCi 24.17: pramadā; Rām 5.9.10: yavan̄i), the Kāmasūtra informs us that there were different types of female companions. In addition to those specifically attached to the goșthi (goșthiparigrahā), there were the prostitutes (veśyā) and the king's chosen women (räjayoșāparigrahā) (2.6.45). A lady belonging to the men's club was a young female who was specially chosen for the role as a type of high-class "escort" (6.6.46). She appreciated artistic activities (3.4.27) and was easily subdued by either mere persistence (5.1.52) or the kind gesture of giving flowers (5.2.21), but she would shy away from goșthis where the attendees exhibited barbaric behaviour (5.6.49). 
In its chapter on the supervisor of the courtesans (ganikädhyakṣa), the Arthaśāstra tells us more about the women-for-hire within the urban environment of the fort (AŚ 2.27). The supervisor's main job was to manage the courtesans (ganikā). He lived in the southern part of the fort, along with dealers in alcohol, food, and meat, the city manager (nagara=nägarika), grain dealers, directors of factories, military officers, prostitutes (rūpajjīvi , lit. 'she who lives off her beauty'), dancers (tālāvara), and members of the Vaiśya caste (AŚ 2.4.11. See Olivelle 2013: 505-506). His principal responsibilities involved the purchase, upbringing, bookkeeping, and eventual sale of a courtesan (AŚ 2.27.6-24). ${ }^{18}$

The courtesan could come from either a courtesan's or another's family, but she should possess beauty, youth, and have artistic inclinations (śilpa) (AŚ 2.27.1). ${ }^{19}$ Courtesans resided among families of performers and theatre folk, all of whom lived in the same district. These neighbours included dancers, actors, singers, musicians, bards, mimes, acrobats, jugglers, wandering troubadours, and those who lived by secrets (AŚ 2.27.25). ${ }^{20}$ The supervisor used royal funds to educate the courtesans, female slaves, and women who lived by the stage in the following arts $($ kala $)$ : song; musical instruments, especially the lute, the flute, and the drum; recitation; as well as dance, performance, writing, painting, knowledge of other's thoughts (i.e., mind-reading), preparation of scents and flower garlands, conversation, massage, and the art of seduction (AŚ 2.27.28). ${ }^{21}$

The courtesans depicted in the Arthaśāstra lived among various kinds of performers and professional theatrical folk, from whom they learned many of the art forms that proved useful in their special role of pleasing men. The description of these women aptly characterise the ladies attached to the goșthī of the Kāmasūtra, and especially their sophistication in the arts, which was the privilege of only certain women. Like the sympotic flute-playing damsels depicted on Greek drinking vases, the ladies of the goșthi were a step above the normal harlots and prostitutes, because they were educated and trained in the different art forms, and particularly in those special skills of entertaining and pleasing men. Because of their acquired talents, they were treated with respect, paid handsomely, and given a place of honour at the goșthi.

\section{THE POETIC GOȘTHH $(K \bar{A} V Y A G O S ̦ T H \bar{I})$}

In their respective social and cultural settings, both the symposion and the gosth $\bar{\imath}$ were essential forums for the development of literature and the theatrical arts. Likewise, both the Greek and Indian men's social gatherings consisted of various types of creativity, which, however, were classified differently. Whereas the inventiveness of the symposion emphasised different forms of metrical composition (e.g. elegies, lyrics, and bawdy poetry in iambic metre), the creativity of the goșthis was divided into different kinds of art forms, the most important being poetry $(k \bar{a} v y a)$, which comprised the dominant intellectual activity in both India and Greece.

\footnotetext{
18 The origin of the word ganikā is unknown, but, related to ganaka 'the calculator or astrologer', it might well have originally referred to a daughter of an astrologer.

19 Olivelle (2013: 567) describes her as a high-class courtesan and distinguishes her from the common prostitute (rūpājīvī, veśȳa).

20 For those "who live by secrets" (i.e. tattletale, female informant), Olivelle (2013: 159) has "women who live by the secret professions".

21 The skill in mind-reading brings to mind divinatory skills often associated with the Romani-speaking or gypsy women.
} 
Already in the Mahābhārata, we learned that paṇịtas composed stories (kathā) at different venues, including the goṣthī (4.42.27). As Siegfried Lienhard shows, the goșthī eventually became the principal environment for the training and development of the poet or kavi in ancient India. Different goșthīs were devoted to different art forms, such as poetry (kāvya), old epics and Purānas (jalpa), dance (natya), and the instrumental music of the flute (vädya) and the lute (viña) (Lienhard 1984: 15-17). Poets were respectable members of the urban and courtly upper classes, who daily worshipped the goddess Sarasvatī and enjoyed the privileges that such a status provided. Their training took place in the company of other poets at the gosthth $\bar{\imath}$ and consisted of various kinds of exercises aimed at gaining mastery of metrical patterns, memory of verses, improvisation, and the composition of verses (Lienhard 1984: 19-21, 150ff).

By the ninth century, the sympotic intellectual element blossomed into different literary and artistic forms dominated by poetry, since gatherings of male poets (kâavyagoșthi $)$ received royal patronage and flourished in the Indian intellectual courtly environment. When art came under the purview of royal patronage, artists received the essential support that allowed them to develop their art forms as livelihood, especially poetry and drama. For example, in his Kâvyamīmāmsāa (or "Theory of Poetry") from the end of the ninth to the beginning of the tenth century CE, Rājaśekhara depicts the assembly of poets at the royal court. In the tenth chapter on the secrets of the poet, the author informs us that large poetry events took place under the auspices of the king, who would periodically host a gathering of poets for the examination and evaluation of their creative skills. The competition would take place at the grand sabha attached to the king's play room (keligrha).

Beginning with the Sanskrit poets, who were seated to the north of the king, savants and poets with different expertise were arranged around the monarch. When finally the king was comfortably seated, the gathering of poets ( $k \bar{a}$ vyagoșth $\bar{l})$ opened with the presentation and evaluation of the different poems. Recalling practices of former great rulers, beginning with the Kușāna King Vāsudeva I and the kings of the Sātavāhana Dynasty, the ruler first honoured the participants and presented them with gifts, gratified them, and fed them, and finally gave them a fee (pāritosikik) for their participation and contributions. He judged the poetry himself and praised the best works and their authors. In addition to poetry, he would periodically permit the recitation of passages from the textbooks (śāstra); for scholars who came from another part of the country, he arranged a different programme, but also gave them respect. During the competition, if a piece of work was deemed worthy, the king would privately whisper in the poet's ear, requesting him to become a member of the king's literary staff, for those he hired benefitted from royal support. In this way, the event was a type of job interview for promising men of letters.

In order to assess potential scholars and poets for the court, the king organised grand assemblies of Brahmans (brahmasabhā) in large cities (mahānagara) for examination in both poetry and scholarship. Those who passed in these two subjects enjoyed travel in the brahman's chariot and the binding of the turban as marks of the intellectual elite and of royal patronage. The major towns where these literary gatherings took place included Ujjayinī (Ujjain in modern Madhya Pradesh) for the examination in poetry and Pạtaliputra (Patna in modern Bihar) for the examination in scholarship, which focused mainly on grammar. The king who held such events

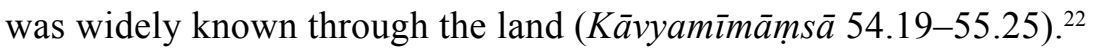

22 See Stchoupak \& Renou 1946: 157-162, where difficult words and passages are discussed. 
In addition to giving a clear description of a courtly examination of poets and scholars, Rājaśekhara informs us that there was memory of such events reaching as far back as Vāsudeva I in the first part of the third century CE, thus setting the Kuṣanna dynasty in the line of the transmission of an important sympotic element. By the time of this Kușāna monarch, the courtly intellectual world had a distinctive Brahmanic śāstric identity, which characterised paṇititas and the literary divisions of poetry (kāvyaśāstra) and grammar (vyākarana).

The testimony of Rājaśekhara, therefore, places the earliest recollection of the royal gathering of poets and the king's involvement in organising and the judging of poets and scholars in the kingdoms of the northern and western portions of India. As late as the ninth century, rulers could trace the sympotic element of mental agility back to the late Kuṣāna rulers.

I would like to conclude this essay with a brief excursion into the social and historical context for sympotic ideas and how they were disseminated and assimilated in ancient India. I focus here on the archaeological and epigraphic evidence for sympotic motifs in Bactria, Gandhāra, and Mathurā in the centuries surrounding the beginning of the Common Era, roughly at the same time as the literary sources discussed above. This affords us the opportunity to examine both literary and material evidence to gauge the history of the Greek symposion in the India.

\section{EVIDENCE FROM MATERIAL REMAINS}

In this section, I examine the presence of sympotic elements in the archaeological artefacts and inscriptions from about the third century BCE to the first century $\mathrm{CE}$ in Bactria and Gandhāra, the Central Asian areas covering modern-day northern Afghanistan, Pakistan, and further east to Mathurā in the north-central part of the Indian subcontinent. I take my inspiration from a recent article by S.J. Kim (2011), who provides a brief overview of the Dionysian elements in Gandhāran and Kușāna-Mathuran art, emphasising the different Indian adaptations of the characteristic sympotic motifs of wine, women, and song. Kim classifies these elements rather broadly as "Dionysiac representations", but on close examination, the artefacts contain distinctive sympotic elements, known from the literary sources. Here, I shall point to parts of the symposion represented in different types of material remains to offer a more complete picture.

\section{Archaeological Evidence}

Examples of Dionysus and Aphrodite in artefacts from Afghanistan indicate the presence of wine and sex among the ruling classes in the late centuries BCE. The examples derive from the 2011 touring exhibit "Afghanistan. Crossroads of the Ancient World" of the National Museum of Afghanistan in Kabul (Hiebert \& Cambon 2011). On the northern border with Tajikistan, at the Greco-Bactrian site of Aï Khanum, excavators discovered a major Greek settlement complete with a gymnasium and theatre (Hiebert \& Cambon 2011: 81-104, 125-126). Among the artefacts unearthed is a bronze handle of a bowl from c. 145 BCE (Fig. 1). At its two ends are images of the same male torso, surrounded by vine leaves, with female breasts coming out of the hair. It represents a type of maenad or female follower of Dionysus (Hiebert \& Cambon 2011: 112, image 13). It is not known exactly what the handles were attached to, but it is possible that they belonged to the krater , the large caldron used to dilute the wine with water at the symposion, depicted below on the pillar from Mathurā. 


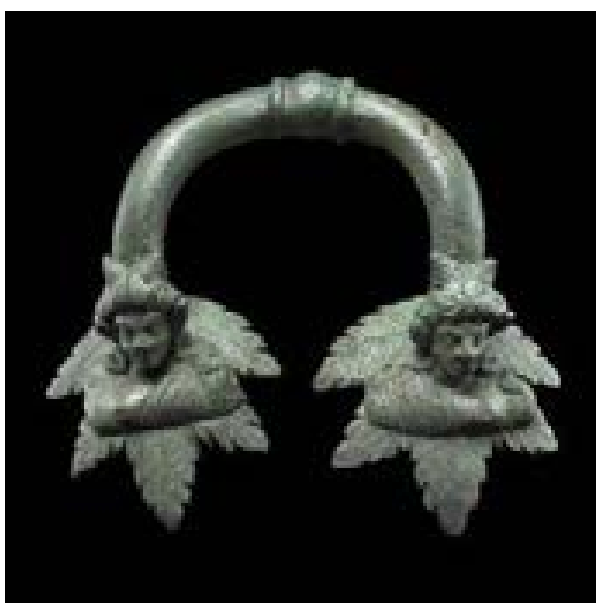

Figure 1 Handle of a bowl from Aï Khanum (c.145 BCE)

At Begram in the Hindu Kush, north of Kabul, we find another important excavation site with a strong Greek cultural presence. Among the various articles from the first century $\mathrm{CE}$, we find several items that indicate the practice of male gatherings to drink wine and enjoy women, two of the three sympotic themes. The harem scenes are indicative of the women's quarters and courtly life depicted in passages from the Kāmasūtra and Arthaśāstra mentioned above. A few exemplary illustrations include:

1. A kantharos drinking vessel (Skt bhäjana, saraka) made of clear rock crystal and decorated with grape leaves and knotted vine shoots (Hiebert \& Cambon 2011: 200-201, image 102). The illustrated drinking cup is typical of the various kinds of drinking vessels found throughout the Greek speaking world, which depict the activities at the symposion (Fig. 2).

2. A small mask of Sileus, a companion of Dionysus, draws a connection to wine (Hiebert \& Cambon 2011: 205, image 109) (Fig. 3).

3. A circular medallion decorated with grapevines, symbolises the importance of wine to the owner (Hiebert \& Cambon 2011: 184-185, image 77) (Fig. 4).

4. A series of eighteen ivory carvings depicting bare-breasted women (Gr. hetaira; Skt. abhisārika, pramadā, veśyā, and/or gaṇikāa) in various poses and enjoying themselves in the confines of the harem. The pieces are of Indian inspiration and probably come from Gandhāra because of the Buddhist theme (Hiebert \& Cambon 2011: 186-195, images 79-96). The last scene (image 96) depicts a gateway into the most private of rooms in the royal compound. The theme is sex, but the style is reminiscent of gateways to Buddhist stūpas (Figs. 5-7).

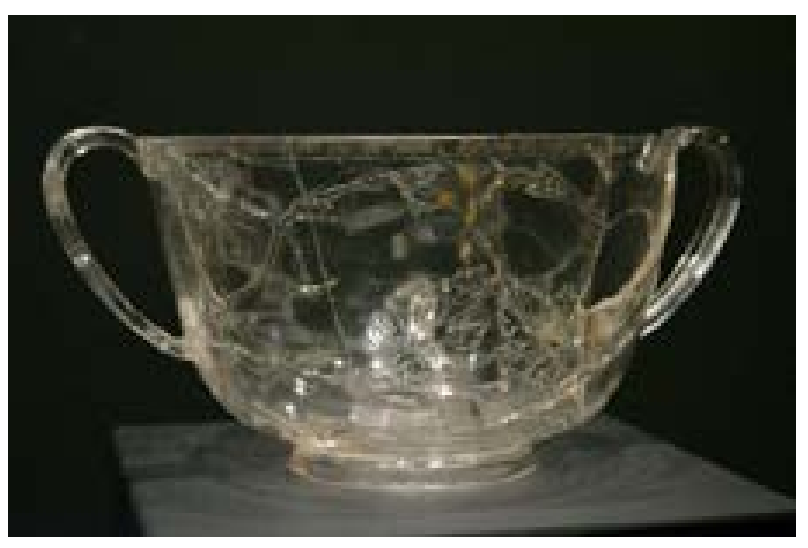

Figure 2 Kantharos from Begram (first century $\mathrm{CE}$ ) 


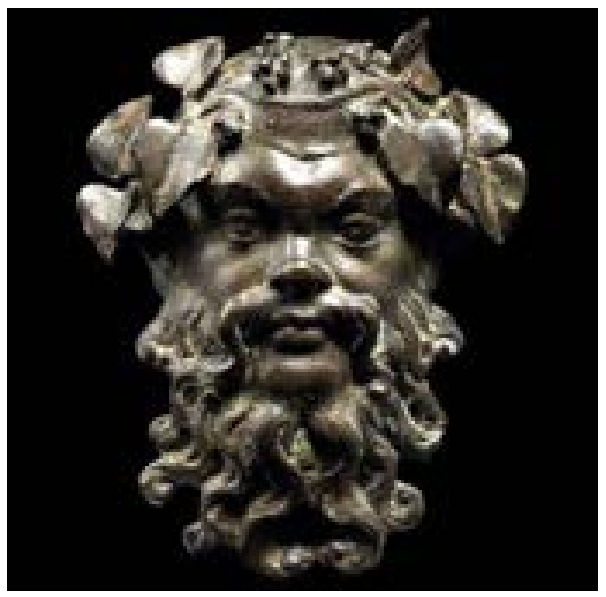

Figure 3 Mask of Silenus from Begram (first century $\mathrm{CE}$ )

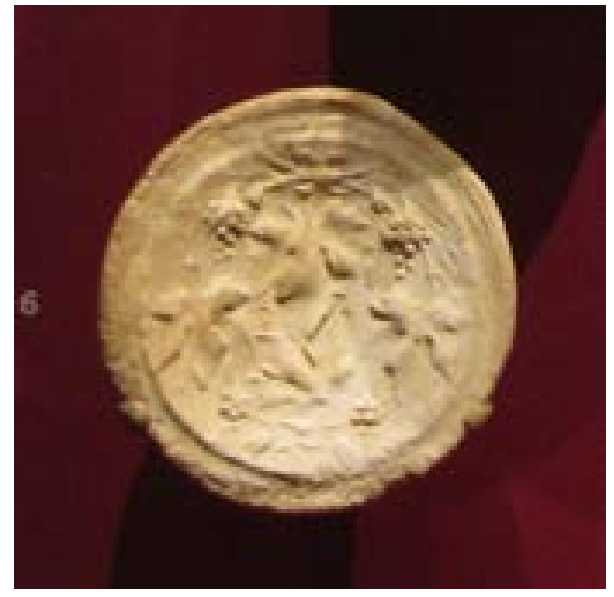

Figure 4 Circular medallion decorated with grape leaves, Begram, first century $\mathrm{CE}$.

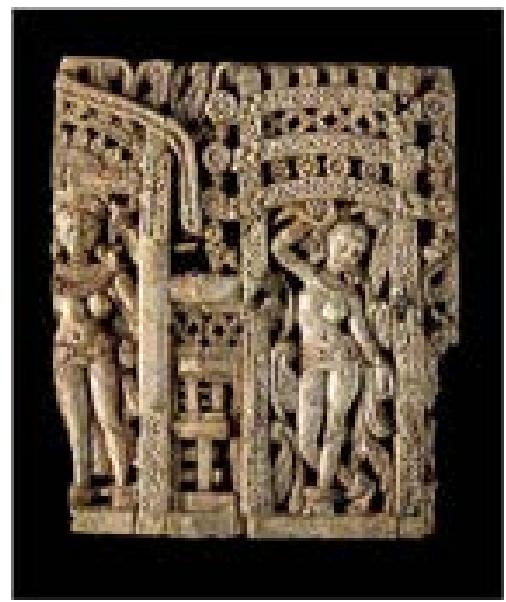

Figure 5 Decorative plaque with women standing under gateways (image 85), Begram, first century CE.

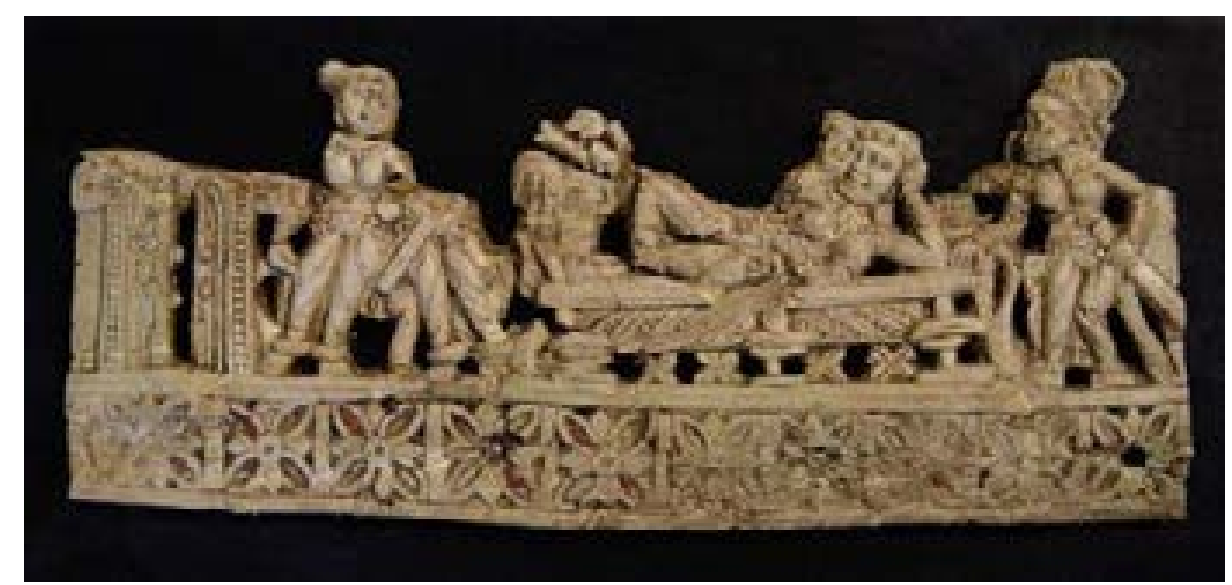

Figure 6 Decorative plaque with a scene from the women's quarters (image 93). Begram, first century CE. 


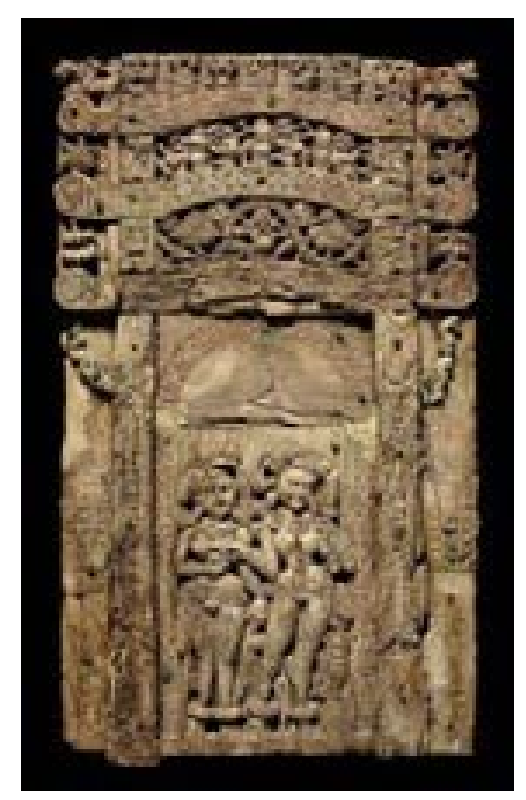

Figure 7 Large decorative plaque with women under a gateway (image 96), Begram, first century CE.

Finally, at Tillya Tepe in north-western Afghanistan there are Dionysian themes on the gold goods deposited in the graves of nomads in the second quarter of the first century CE. The first is a pair of clasps, gold with turquoise, which depict Dionysus and Aridne, along with Sileius, representing the cult of wine and women associated with the symposion (Fig. 8). The second is an appliqué, called the Aphrodite of Bactria, which represents the sexual side of the cult of Dionysus (Hiebert \& Cambon 2011: 286-287, image 216 (clasps), and 288, image 217 (appliqué)) (Fig. 9).

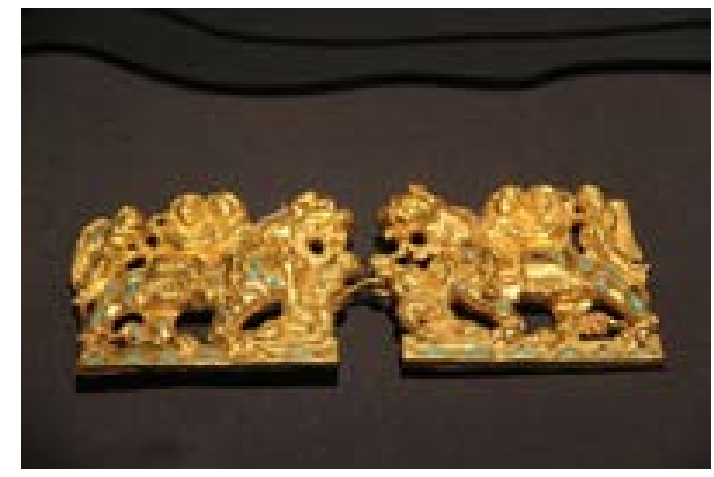

Figure 8 Pair of clasps: Dionysos and Ariadna from Tillya Tepe (second quarter of the first century $\mathrm{CE}$ )

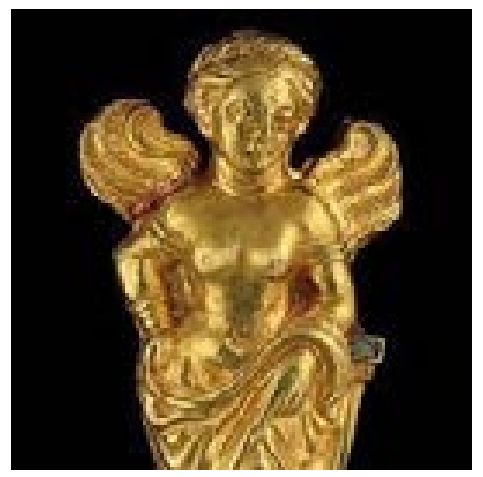

Figure 9 Appliqué: Aphrodite of Bactria, Tillya Tepe (second quarter of the first century $\mathrm{CE}$ )

The Afghanistan objects point to the presence of sympotic elements in both their symbolic and material representations from the beginning of the first century of the Common Era. This form of men's social gathering moved with the rulers as they advanced from Bactria, over the Hindu Kush, and into the Gandhāra regions of Pakistan and northwest India.

Another example of the depiction of sympotic themes is witnessed in the so-called "toilet bowls" from Gandhāra, dating from the second century BCE to the second century CE. This collection of bowls is part of a private collection, so their exact providence is regrettably 
unknown. They are catalogued under the general designation of Gandhāra (Rapin n.d.). The central sympotic themes of wine, women, and song are shown as:

1. an amorous couple with a musician (Fig. 10),

2. love-making (Fig. 11),

3. a man on a lounge (Gr. kline, Skt. śayyā, śayanāsana) with a lover accompanied by a female musician (Fig. 12),

4. a group of musicians, one with a flute (Gr. Aulos; Skt. vādyā) (Fig. 13),

5. a drinking couple (Figs 14-15), one clearly with drinking vessels (Gr. Kylis; Skt. bhäjana, saraka) (Fig. 14),

6. a form of learning, resembling the guru-śesya style of learning in India (Fig. 16), and

7. scenes of libations (Gr. synomosia; Skt. äśis): offering to an ascetic (Fig. 17) and offering to a divinity (perhaps Dionysus) (Fig. 18). All these images depict different parts of the gathering of men from the privileged classes enjoying a night drinking at the symposion.

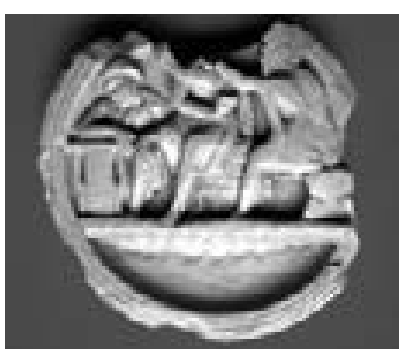

Figure 10

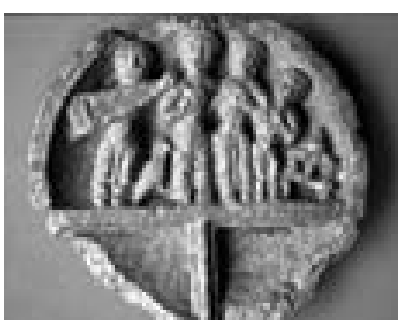

Figure 13

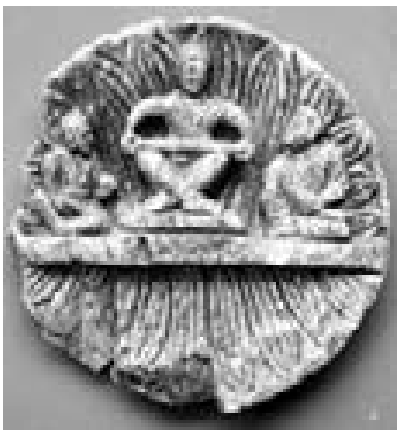

Figure 16

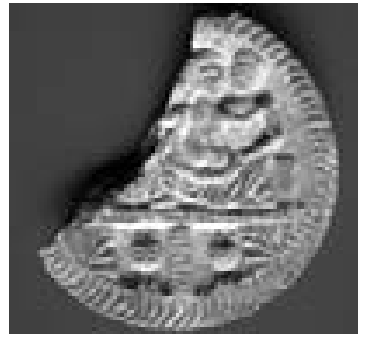

Figure 11

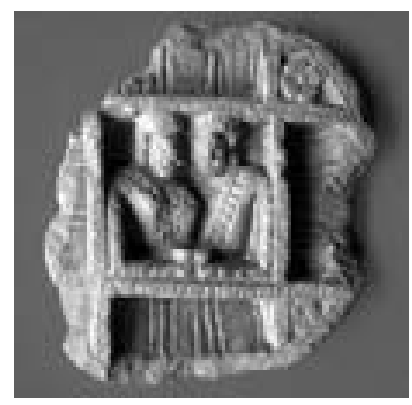

Figure 14

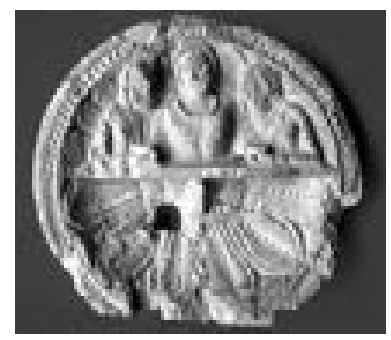

Figure 17

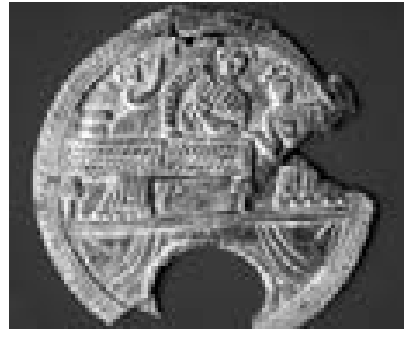

Figure 12

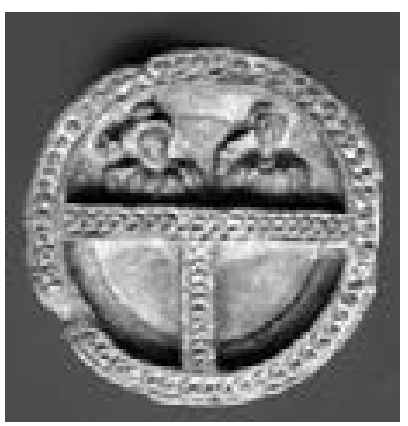

Figure 15

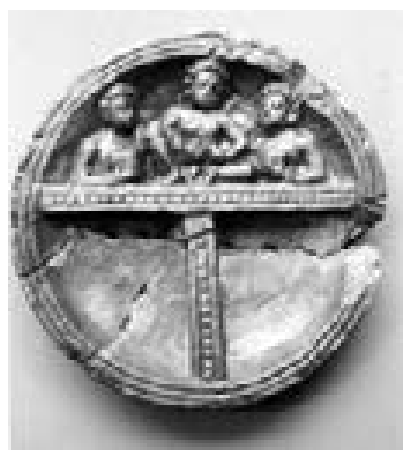

Figure 18 
Finally, the largest single collection of sympotic motifs in one place is the stone column from Mathurā in the central part of the Indian subcontinent, dating from the first century CE to $320 \mathrm{CE}$ and now housed at the Cleveland Museum of Art (\#1977.34). ${ }^{23}$ It represents perhaps the best example of the symposion and its adaptation into the culture of the brahmans. The following are the sympotic themes represented on this pillar (Fig. 19):

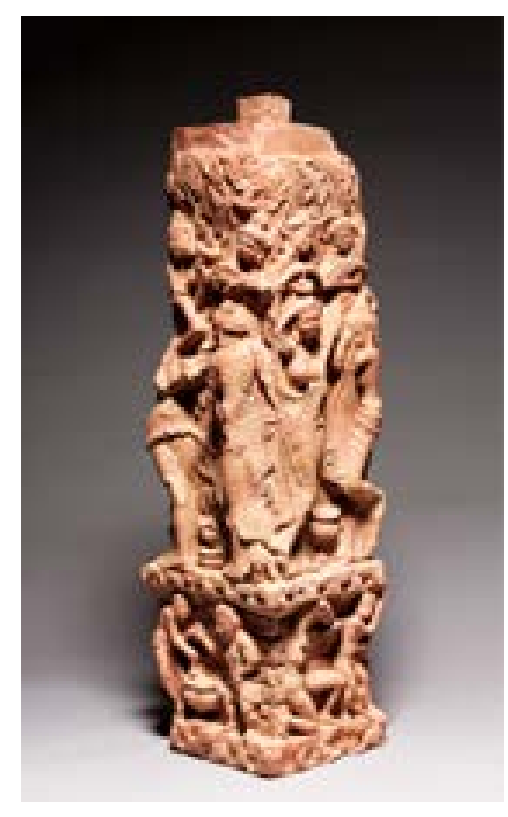

Figure 19 Corner railing pillar with drinking scenes, yakșis, and musicians, Mathurā, first century-320 CE (\#1977.34).
1. grapevines;

2. wine-serving vessels;

3. wine-drinking vessels (Gr. kanthros, kylis; Skt. bhājana, saraka);

4. a krater with two men: one, the leader (archos, basileus; Skt. nāyaka), who take cares of the pot of wine and water, while the other person is either pouring something (i.e. water to dilute) in or extracting the wine from the krater; and

5. scantily clad females (Gr. Hetaira; Skt. abhisārika, pramadā, veśy $\bar{a}$, and/or ganikā) performing various activities: some are moving/dancing; and some playing different musical instruments (flute, lyre, harp, cymbals), drinking wine, and writing or engraving on a board.

An unbroken transmission of the Greek social custom of the symposion drinking party is confirmed from archaeological remains from Bactria and Gandhāra, but also from further east into the subcontinent at the Buddhist site of Mathurā.

\section{Epigraphic Evidence}

The evidence that Harry Falk has marshalled from epigraphic and numismatic sources paints a clear picture of the movement and adaptation of Greek culture and thought from Gandhāra to Mathurā, located in the central part of the subcontinent, from the last centuries BCE to the early centuries CE. These adaptations apply principally to the ruling classes and include the use of Greek titles and the worship of Greek gods, often taking on the names of local deities (Falk 2013).

The use of the Gandhāran title mahākșatrapa was used from 40 to about 90 CE by the last ruler of Mathurā, Śộāsa, whose family moved from Jammu to Mathurāa, and by the Kardamaka dynasty as far as Ujjain until $330 \mathrm{CE}$ (Falk 2013: 279). Similarly, a dedicatory inscription from the second century CE, during the rule of the Kușāna King Huviṣka, now housed in the Mathura Museum, shows adaptations from Gandhāra (Falk 2013: 290-291).

One important find is the private collection of goods from the Mohmand Agency north of the Khyber Pass on the border of Pakistan, dating from about 150-50 BCE. This collection contains typical Greek donations, including silver plates (phialē), three of which bear inscriptions written in Greek or Gāndhārī with Kharoșṭhī letters, and one is bilingual. A stone

23 The museum has provided a detailed, high-resolution image of the piece on its website <clevelandart.org/ $\operatorname{art} / 1977.34>$.. 
beaker from the collection suggests a sympotic drinking vessel. It bears the inscription: "this vessel serves easiness and vigour" (io patrika ksemake vayake), ${ }^{24}$ which means that the cup was used exclusively for pleasure and enjoyment (Gr. Euphorsyne; Skt. krid̄a), with its contents providing the energy. All this points to a vessel for drinking wine.

The archaeological and inscriptional evidences illuminate the extent of Greek customs, practices, and knowledge that were transmitted from Gandhāra into the central parts of the Indian subcontinent during the early centuries of the Common Era. Along the way, these were transformed into something familiar to the privileged Indians and their own local customs, beliefs, and practices.

\section{A HISTORICAL EXCURSION}

Having provided literary, archaeological, and epigraphic evidence for the transmission and adaptation of the Greek symposion into the Indian subcontinent, I offer a historical overview of the transmission process, with missing pieces to be filled in by future scholarship. The examined evidence suggests that basic sympotic elements were part of the social matrix of the Indo-Greeks in the north-western parts of the Indian subcontinent in antiquity. The first indication of these in Western sources comes in the form of a legend about the Greek general Dionysus (variously known as Lenaias and Katapogon), who is said to have conquered the Indians before Alexander and introduced the custom of wine consumption and sex to the people whose descendants include the Kalaśa of the present-day Hindu Kush region of eastern Afghanistan and western Pakistan.

The legend is first recounted in reports by the Greek envoy Megasthenes, who was sent in $303 \mathrm{BCE}$ to the court of Sandracottus (Candragupta Maurya) in Pālibrothra (i.e. Pātaliputra), or modern-day Patna in Bihar, and summarised and embellished by Arrian in his Indika in the second century CE. These Greek sources in a general way are supported by the archaeological and epigraphic records from the region. Megasthenes tells us that in order to give his troops time to recover from the heat and disease of the plains of Afghanistan, Dionysus moved his army to a place he called Meros in the nearby mountains. The climatic conditions being suitable there, he introduced the native peoples of the area to the planting and cultivation of grape vines, winemaking, and other arts that promoted a man's well-being. He taught them to worship the Greek gods and gave them laws and courts to uphold them. In return, the locals treated him as a deity. As a distinctive battle tactic, Dionysus used alcohol and sex to subjugate the men of the Indian armies.

Arrian then informs us that the district founded by Dionysus was called Nysaea, and its main city was known as Nysa, which probably refers to a town along the Kabul River near the Afghan province of Nuristan, which is close to its current border with Pakistan (Karttunen 1989: 56; Carter 1968: 136-137). When Alexander later came to the region, he noticed that these people were of Greek descent and thereby allowed them to live and maintain their customs. He appointed Acuphis as governor and worshipped with his troops at the temple of Dionysus in the manner of the Macedonian symposion, which emphasised wine and women (McCrindle 1877: 344; McCrindle 1876: 85, 329-330; Chinnock 1884: 265-267).

Although generally understood to be legend, there are parts of the story that seem to ring true, as we can understand from the sources previously examined. These include especially the sympotic elements of alcohol (wine) and sex, and the worship of the patron deity, who

24 Falk 2013: 177. The translation here is a slight modification of Falk's. 
for the early Indo-Greeks was Dionysus. ${ }^{25}$ Irrespective of who the first conqueror was, a form of the Greek symposion probably with Macedonian characteristics existed from the time of Alexander in Bactria, Gandhāra, and the north-central parts of the Indian subcontinent. It was from Gandhāra that the alcohol merchants of the Arthaśāstra likely imported their wine.

Alexander invaded and conquered the regions of the northwest and the western part of the subcontinent from about 326 BCE. In his wake, he left satraps to rule his captured land, which included Aï Khanum, Begram, Takșaśilā, the Punjab, and the lower Indus (Neelis 2011: 98-101).

Following him, the Bactrians and Kușannas conquered and ruled the area from the second century BCE. Their influence is clearly recorded on the artefacts unearthed by archaeologists, which date from the middle of the second century BCE. Notable influences are found in the city of Takșaśilā in the ancient Gandhāra region of the northwest, which was known from before Alexander's time as a major trading centre and city of culture and the arts (Neelis 2011: 102-108; Karttunen 1989: 62). It was one of the capitals of the Kușānas, who ruled most of northern India from the mid-first century BCE to the mid-third century CE. As previously noticed in the Kāvyamīmāmsāa, one of the last of the Kusānana kings, Vāsudeva, was remembered for hosting a large gathering of scholars and poets at the royal poetry clubs at the end of the ninth century.

\section{Alcohol and Women}

Evidence of the two principal sympotic elements of alcohol (wine) and sex occur early in the northwest of the subcontinent. There is ample evidence that viticulture was known in the eastern parts of Afghanistan after the time of Alexander. The archaeological and art historical remains from sites in Bactria, Gandhāra, and Mathurā indicate that typical sympotic types of drinking binges and sexual fun were part of the social activity of the privileged elite, which spread from the north-western as far as Ujjain in the central region of India proper, especially during the period of the Kușānas (Carter 1968; Falk 2010; Ray 2014). Sympotic drinking and sex were so common in these areas of early Buddhism that Buddhists, who were otherwise forbidden to consume alcohol, except perhaps for medicinal purposes, participated in the popular winemaking festivals, since knowledge of medical recipes permitted them to prepare different kinds of spirits (Falk 2009). Already in the Pāli canon, references to alcoholic medical preparations can be found, including a type of fermented drink (soviraka) (See Zysk 2021: 144-149). It would appear that the techniques and recipes for alcoholic drinks were a part of Buddhist medicine from early times.

By the time of the anonymous Periplus Maris Erythraei, composed between 40 and $70 \mathrm{CE}$, early Egyptian Roman trade was already taking place along the coastal areas of the southwest and south-east of India (Neelis 2011: 126-127; Schoff 1974: 8-15). In this connection, Karttunen reports that in the Tamil regions of South India, there is a story in the Tamil Sangam literature from the first century BCE to the fifth century CE which tells about alcohol brought by Yavanas in beautiful bowls and given to girls with shining bangles to drink in golden drinking vessels distributed by well-behaved suppliants (iravalar). The Yavanas (most likely here referring to Romans), who remained in the region, served as bodyguards to Tamil kings, and were known for their lamp-making, carpentry, cart-making, and makara-shaped lutes (Karttunen 2015: 294-300 (and note)). The episode described in the Puranānūru (56.17-20) fits the image

25 On the Dionysus controversy, see Karttunen 1989: 210-218. 
of the Indian drinking binge found in the Indian medical texts and mentioned in the Kāmasūtra. In this Tamil version, the reference to the bowl of alcohol brings to mind the sympotic krater .

The evidence indicates that central sympotic elements of drinking and sex existed in the north-west of South Asia from at least the time of Alexander. They were subsumed into the Indian courtly life during the subsequent periods, especially by Kuṣannas, and were adapted, imitated, and interwoven in the aristocratic social and courtly fabric of upper-class Indians under the Sanskrit name goșthi. It was probably during this time that Brahmanic and perhaps also Buddhist religious ideology and practice influenced the activities of the men's social gatherings, so that the emphasis gradually tended to move away from drinking and women and towards intellectual and literary activities.

It is well known that sex, especially among the privileged aristocratic classes, never disappeared. Evidence of this is found in the portrayals of sex surrounding the temples at Konark in Orissa and Khajuraho in Madhya Pradesh, and in the blossoming of erotic literature from the eleventh century, when it picks up in earnest nearly a millennium after the Kāmasūtra is said to have been composed. Men's enjoyment of sex persisted as a favourite pastime of the elite until perhaps the arrival of the Victorian British in premodern India.

As already seen in classical antiquity, especially in the two versions of the Symposion composed by Xenophon and Plato in the fourth century BCE, the tension between physical enjoyment and the exercising of the intellect existed in ancient Greece as well. As in the classical European societies, royal patronage of men's societies and artistic guilds in ancient India paved the way for the flowering of Sanskrit poetry and dramatic arts from the early centuries of the Common Era. The different adaptations and imitations of the sympotic elements gave rise to the unique male social institution that came to be known in ancient India as the gosth $\bar{l}$, which played a central role in the development of the literary and theatrical arts.

\section{CONCLUSIONS}

The evidence thus far presented indicates that central sympotic elements of drinking and sex existed in the regions of Bactria and Gandhāra shortly after Alexander conquered them and set up satraps to govern. The third sympotic element, involving mental activity, has come to us via Sanskrit literature. These three sympotic practices were subsumed into the Indian courtly and urban life during the Kușana period and were adapted, imitated, and interwoven in the aristocratic, social, and courtly fabric of the Indians under the Sanskrit names of sabhā and goșthī. It was probably during this time that Brahmanic and perhaps also Buddhist religious ideology and practice influenced the activities of the men's social gatherings, so that the emphasis moved away from drinking and women to emphasise intellectual and literary activities.

As already seen in classical antiquity, the tension between physical enjoyment and intellectual development was present in ancient India as well. Likewise, as in the classical European societies, royal patronage of men's societies and artistic guilds in ancient India paved the way for the flowering of Sanskrit poetry and theatre from the early centuries of the Common Era. Adaptations and imitations of the sympotic elements were the nourishment that fed the indigenous seeds of the social life of elite men in ancient Indian society. Once germinated, these seeds grew into a purely Indian institution. 


\section{ABBREVIATIONS}

$\begin{array}{ll}\text { Ah } & \text { Așṭāngahṛdayasaṃhitā } \\ \text { As } & \text { Aș̣āñgasaṃgraha } \\ \text { AŚ } & \text { Arthasāāstra (ed. Kangle 1960) } \\ \mathrm{Ca} & \text { Carakasaṃhitā } \\ \mathrm{Ci} & \text { Cikitsāsthāna } \\ \mathrm{KS} & \text { Kāmasūtra } \\ \text { Mbh } & \text { Mahābharata (critical edition) } \\ \text { Rām } & \text { Rāmāyaṇa (critical edition) }\end{array}$

\section{REFERENCES}

ĀṬhaVAle, Ananta Dāmodara (ed.) 1980. Aștāñngasangrahaḥ induvyākhyāsahitah. Pune: Maheś Ananta Āthavale. Bнатт, G.H. et al. (eds) 1958-1975. The Vālmīki-Rāmāyaṇa. 7 vols. Baroda: Oriental Institute.

Blinkenberg, Christian \& Knud Friss Johansen 1924-1963. Corpus vasorum antiquorum. Danemark. Copenhague; Musée National (Collection des Antiquités Classiques), I-VIII. Paris: Librairie Ancienne Édouard Champon; Copenhagen: Librairie V. Pio. Povl Branner and Eirnar Munksgaard (Union Académique Internationale).

BüHLER, Georg 1892. The Peheva Inscription from the Temple of Garībnāth. Epigraphia Indica 1: 184-190.

CARTER, Martha 1968. Dionysiac Aspects of Kushān Art. Ars Orientalis 7: 121-146.

Cazzato, Vanessa (ed.) 2018. The Symposion: Drinking Greek Style: Essays on Greek Pleasure 1983-2017. Oswyn Murray. Oxford: OUP.

Chinnock, E.J. 1884. The Anabasis of Alexander; or The History of the Wars and Conquests of Alexander the Great. London: Hodder and Stoughton.

Dalal, C.D. \& R.A. SAstry (ed.) 1934. Kāvyamīmāmsāa of Rājaśekhara. 3rd edn. Rev. \& enl. K.S. Ramaswami Sastri Siromani. (Gaekwad's Oriental Series 1) Baroda: Oriental Institute.

DAS, Rahul P. \& Gerhard MEISER 2002. Geregeltes Ungestüm: Bruderschaften und Jugendbünde bei indogermanischen Völkern. Bremen: Hempen Verlag.

Derrett, J. Duncan M. 2006. Versatility, Angles and Space: The Meaning of Buddhist and non-Buddhist Parallels. Journal of the Royal Asiatic Society 16(3): 231-242.

Dietler, Michael \& Brian Hayden (eds) 2001. Feasts: Archaeological and Ethnographic Perspectives on Food, Politics, and Power. Tuscaloosa, AL: The University of Alabama Press.

DietLer, Michael 2006. Alcohol: Anthropological/Archaeological Perspectives. Annual Review of Anthropology 25: 229-249.

FALK, Harry 1986. Bruderschaft und Würfelspiel: Untersuchungen zur Entwicklungsgeschichte des Vedischen Opfers. Freiburg: Hedwig Falk.

FALK, Harry 2009. Making Wine in Gandhara under Buddhist Monastic Supervision. Bulletin of the Asia Institute 23: $65-78$.

FALK, Harry 2010. Libation Trays from Gandhara. Bulletin of the Asia Institute 24: 89-113.

FALK, Harry 2013. Hariśyenalekhapañcāsikā: Fifty Selected Papers on Indian Epigraphy and Chronology. Selected and prepared for publication with indices by Britta Schneider and Ingo Strauch in collaboration with Caren Dreyer and Andria Schlosser. Bremen: Hempen Verlag.

Fischer-Hansen, Tobias 2004. Corpus Vasorum Antiquorum. Danmark. Ny Carlsberg Glyptotek. Fasc. 1; Danemark Fasc. 10. Copenhagen: Ny Carlsberg Glyptotek and the Royal Danish Academy of Sciences and Letters.

Fisher, Nicholas R. 1988. Greek Associations, Symposia, and Clubs. In: M. Grant \& R. Kitzinger (eds), Civilization of the Ancient Mediterranean: Greece and Rome, II: 1167-1197. NY: Charles Scribner's Sons.

Ford, Andrew 2002. The Origins of Criticism: Literary Culture and Poetic Theory in Classical Greece. Princeton, NJ: PUP.

GAI, G.S. 1959-1960. No. 6. Jalore Inscription of Chahamana Chachigadeva, V.S. 1331. Epigraphia Indica 33: 46-48.

GOMPERTS, Amrit 2017. Kāmaśāstra in Java and Bali. Traditional South Asian Medicine 9: 136-199. 
Hiebert, Fredrik \& Pierre Cambon 2011. Afghanistan: Crossroads of the Ancient World. London: British Museum Press. Hultzsch, E. 1882. A Chaulukya Grant Dated 1207 AD. Indian Antiquary 11: 337-340.

Jennings, Justin, Kathleen L. Antrobus, Sam J. Atencio, Erin Glavich, Rebecca Johnson, German Loffler \& Christine Luu. 2005. "Drinking Beer in a Blissful Mood": Alcohol Production, Operational Chains, and Feasting in the Ancient World. Current Anthropology 42: 275-303.

Kangle, R.P. 1960. The Kautilīya Arthaśāstra, I (edition). (University of Bombay Studies: Sanskrit, Prakrit and Pali 1) Bombay: University of Bombay.

Karttunen, Klaus 1989. India in Early Greek Literature. (Studia Orientalia 65) Helsinki: Finnish Oriental Society.

KARTtUnen, Klaus 2015. Yonas and Yavanas in Indian Literature. (Studia Orientalia 116) Helsinki: Finnish Oriental Society.

KedĀRAnĀTHA, Durgāprasāda (ed.) 1900. ŚrīVātsyāyanapraṇītạ̣ Kāmasūtram. Yaśodharaviracitayā Jayamañgalākhyayā ṭīkayā sametam. dvitīyam saṃskaraṇam... Mumbai: Nirṇayasāgara Press.

Kielhorn, F. 1896-1897. Deogaḍh Pillar Inscription of Bhojadeva of Kanauj; [Vikrama] Samvvat 919. Epigraphia Indica 4: 309-310.

KIM, SeungJung 2011. The Beginnings of the East-West Dialogue: An Examination of Dionysiac Representations in Gandharan and Kushan-Mathuran Art. In: M.Y.L. Huang (ed.), Beyond Boundaries: East and West CrossCultural Encounters: 16-35. Newcastle-upon-Tyne: Cambridge Scholars Publishers.

KuṇṬ, Aṇnā Moreśvara et al. (ed.) 1982. Aș̣āñgahṛdayasaṃhitam. Śrīmadaruṇadattavircitayā Sarvāngasundarākhyayā vyākhyayā, hemādripraṇītayā Āyurvedasāyanāhvayā ț̄ikayā ca samullasitam. 1939, repr. (Jaikarishnadas Ayurveda Series 52) Varanasi: Caukhambha Orientalia.

Lamb, W.R.M. (tr.) 1925. Plato with an English Translation, V: Lysis, Symposium, Gorgias. (Loeb Classical Library) London: William Heinemann: Putnam's Sons.

Lienhard, Siegfried 1984. A History of Classical Poetry: Sanskrit-Pali-Prakrit. (A History of Indian Literature 3:1) Wiesbaden: Otto Harrassowitz.

Lissarrague, François 1990. The Aesthetics of the Greek Banquet: Images of Wine and Ritual. Tr. Andrew SzegedyMaszak. Princeton, NJ: PUP.

Marchant, E.C. \& O.J. Todd (tr.) 1997. Xenophon: Memorabilia, Oeconomicus, Symposium, Apology. 1923, repr. (Loeb Classical Library) Cambridge: HUP.

McCrindle, J.W. 1876. Translation of the Indica of Arrian. Indian Antiquary 5: 85-108, 329-340.

McCrindLe, J.W. 1877. The Fragments of the Indika of Megasthenes. Indian Antiquary 6: 113-135, 236-250, 333-349.

Melander, Torben 1999. Corpus Vasorum Antiquorum. Danemark. Thorvaldsens Museum (Collection des Antiquités). Fasc. 1; Danemark Fasc. 9. Copenhagen: Thorvaldsens Museum and Académie Royale des Sciences et des Lettres du Danemark.

Meulenbeld, Gerrit Jan 1999-2002. A History of Indian Medical Literature. 3 Vols. Groningen: Egbert Forsten.

Mirashi, V.V. (ed.) 1955. Bagh Cave Plate of Subandhu. Corpus Inscriptionum Indicarum 4: 19-21.

MiRASHI, V.V. 1937-1938. Kaman Stone Inscription. Epigraphia Indica 24: 329-336.

Mooss, N.S. Vayaskara (ed.) 1981. Aștāingahṛdayasamhitā with the Śaśilekhā Commentary of Indu, IV. 2nd edn. (Vaidyasarathy Series S-4) Kottayam: Vaidyasarathy Press.

Murray, Oswyn (ed.) 1990. Sympotica: A Symposium on the Symposion. Oxford: Clarendon Press.

Murray, Oswyn 2009. The Culture of the Symposion. In: K.A. RaAflaub \& H. von Wees (ed.), A Companion to Archaic Greece: 508-523. Sussex: Wiley-Blackwell.

Murthy, K.R. Srikantha (tr.) 1992. Vāgbhața’s Aștāñnga [sic.] Hṛdayam, II. (Jaikrishnadas Ayurveda Series 27) Varanasi: Krishnadas Academy.

NeELIS, Jason 2011. Early Buddhist Transmission and Trade Networks: Mobility and Exchange within and beyond the Northwestern Borderlands of South Asia. (Dynamics in the History of Religion 2) Leiden: Brill.

Olivelle, Patrick 2013. King, Governance, and Law in Ancient India: Kautilya Arthaśāstra. NY: OUP.

Osborne, Robin 2014. Intoxication and Sociality: The Symposium in the Ancient Greek World. Past and Present 222, Supplement 9: 34-60.

Rapin, Claude n.d. The Gandharan Toilet Trays and Central Asian Roads of Commerce. <claude.rapin.free. fr/5Gandhara7\%20images_fichiers/5GandharaCLR7.htm>, accessed 5 Sept. 2020. 
RaY, Ardhendu 2014. Wine Production and Consumption: Archaeological Evidence from Sanghol. Proceedings of the Indian History Congress 75: 1135-1140.

ŚĀsTRIN, Dāmodara Gosvāmin (ed.) 1929. The Kāmasūtra with the Commentary Jayamañgalā of Yaśodhara. (Kashi Sanskrit Series (Haridās Sanskrit Granthamālā) 29) Banaras: Jai Krishnadas-Haridas Gupta.

ŚĀSTRIN, Śr̄̄haridatta (ed.) 1940. Carakasaṃhitā. Mahāmahopādhyāyacaraka-caturānanacakrapāṇidattavicaritayā Āyurvedadīpikāvyākhyayā ... śrī vāgbhațaśișyācāryavarajajjaṭaviracitayā Nirantarapadavyākhyayā ca saṃlitā, II. 2nd edn. Lahore: Motilal Banarsidass.

Schoff, Wilfred H. 1974. The Periplus of the Erythraean Sea. 1912 repr. New Delhi: Munshiram Manoharlal Publishers.

Schwanbeck, E.A. 1846. Megasthenis Indica. Fragmenta collegit. Bonnae: Sumptibus Pleimesii Bibliopolae.

Stchoupak, Nadine \& Louis Renou (tr.) 1946. La Kāvyamìmāmsāa de Rājaśekhara. (Cahiers de la Société Asiatique 8) Paris: Imprimerie Nationale.

Subrahmanya Aiyer, K.V. 1937-1938. Regulations of Sabha from Two Uttaramallur Inscriptions. Epigraphia Indica 24: $27-42$.

Sukthankar, Vishnu S. et al. (eds) 1933-1959. The Mahābhārata. 19 vols. Poona: Bhandarkar Oriental Research Institute.

TriKamJI, Jādavaji (ed.) 1980. Suśrutasamhitā of Suśruta with the Nibandhasaṃraha commentary of Śrī Dalhaṇāchārya and the Nyāyacandrikā Pañjikā of Śri Gayadāsāchārya on the Nidānasthāna. 1938 repr. (Jaikrishnadas Ayurveda Series 34) Varanasi: Chaukhambha Orientalia.

Trikamj, Jādavaji (ed.) 1981. The Charakasamhitā of Agniveśa. Rev. Charaka and Dridhabala, with the ĀyurvedaDīpikā Commentary of Chakrapaṇidatta. 1941, repr. Delhi: Munshiram Manoharlal.

VAIDYA, Parashuram Lakshman (ed.) 1967-1972. The Pratīka-Index of the Mahābhārata. 6 vols. Poona: Bhandarkar Oriental Research Institute.

Valavanis, Panos \& Dimitris Kourkoumelis 1996. Drinking Vessels. Athens: The Hatzimichalis Estate.

Venkatasubbiah, A. \& E. Müller 1914. The Kalas. Journal of the Royal Asiatic Society 46(2): 355-367.

Venkatasubbiah, A. 1911. The Kalās. Inaugural Dissertation, presented to the Philosophy Faculty of the University of Bern for the degree of doctor of philosophy. Adyar, Madras: The Vasanta Press.

Vermant, Jean-Pierre (ed.) 1995. The Greeks. Tr. C. Lambert \& T.L. Fagen. Chicago: UCP.

Vetta, Massimo 1996. The Culture of the Symposium. In: J.-L. Flandrin \& M. Montanari (eds), Food: A Culinary History from Antiqity to the Present: 96-105. NY: Columbia University Press.

VICKERS, Michael 1975. Greek Symposia. London: The Joint Association of Classical Teachers.

VYAS, Ramkrishna et al. (eds) The Pāda-Index of the Vālmīki-Rāmāyaṇa. 3 vols. Vadodara: Oriental Institute.

ZYSK, Kenneth G. 2018. Greek and Indian Physiognomics. Journal of the American Oriental Society 138(2): 313-325.

ZYsk, Kenneth G. 2021. Asceticism and Healing in Ancient India: Medicine in the Buddhist Monastary. 2nd rev. \& enl. edn. Delhi: Motilal Banarsidass.

ZYSK, Kenneth G. \& Tsumoto Yamashita 2019. Sanskrit Medical Scholasticism: Jajjața's Nirantarapadavyākhyā and Other Commentaries on the Carakasaṃhitā, Cikitsāsthāna 2.1. eJournal of Indian Medicine 10: 1-113. 


\section{APPENDIX: A PRELIMINARY LIST OF GREEK AND SANSKRIT EQUIVALENTS}

In addition to the Sanskrit samāpannaka 'drinking together', a list of other equivalent terms in this context helps to illustrate the process by which a Greek social institution was integrated and adapted to an Indian context (Table 1). A similar collection of specialised terms is already assembled for the Greek and Sanskrit terminology pertaining to physiognomy. ${ }^{26}$ This lexical catalogue applies to the sympotic context of the goșthi

Table 1 A preliminary list of Greek and Sanskrit equivalents

\begin{tabular}{l|l|l} 
Greek & Sanskrit & English \\
\hline agathos daimon & arthin & spirit of vineyard, deserving spirit (?) \\
\hline andrōn & vāsagṛha, deśa, āpānabhūmi, pānabhūmi & $\begin{array}{l}\text { men's room; seasonal place; } \\
\text { the refuge for drinking }\end{array}$ \\
\hline archos, & nāyaka & leader, master of ceremonies \\
\hline aulos & vādya & flute, wind instrument \\
\hline basileus & nāyaka & leader, master of ceremonies \\
\hline deipnon/dorpon & bhojana & dining/dinner \\
\hline hetairos & sahāya, nāgaraka, sakhi, vayasya & male companion, male citizen \\
\hline hetaira & abhisārikā, pramadā, veśyā, gaṇikāa & $\begin{array}{l}\text { female companion, young woman, } \\
\text { prostitute, courtesan }\end{array}$ \\
\hline euphorsyne & krị̣̄ā & amusement, fun \\
\hline kantharos & bhājana, saraka & drinking vessel \\
\hline kline & śayyā, śayanāsana & couch, lounge-chair \\
\hline kylis & bhājana, saraka & drinking vessel \\
\hline megaron & sabhā & large assembly hall \\
\hline skolion & kāvyasamasyā & poetry by turns \\
\hline sympósion & samāpānaka, āpanaka, pāna & drinking together, drinking binge \\
\hline synomosia & $\bar{a}$ śis & vows, benedictions uttered together \\
\hline
\end{tabular}

26 Zysk 2018. 